
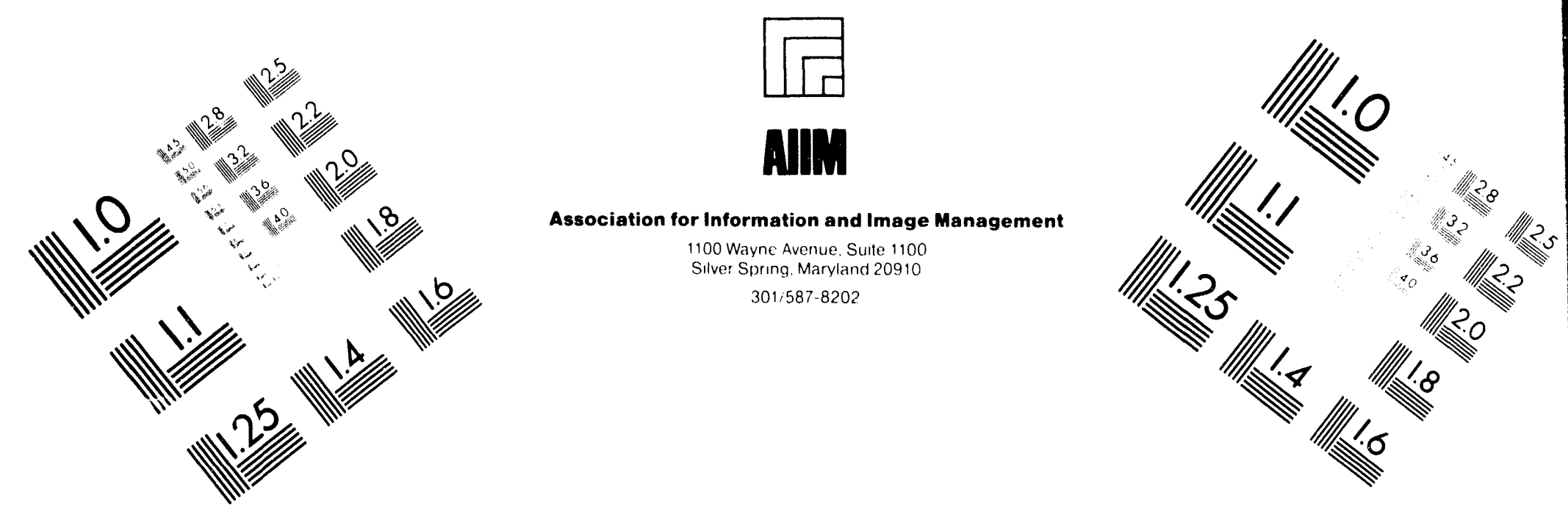

\title{
Centimeter
}

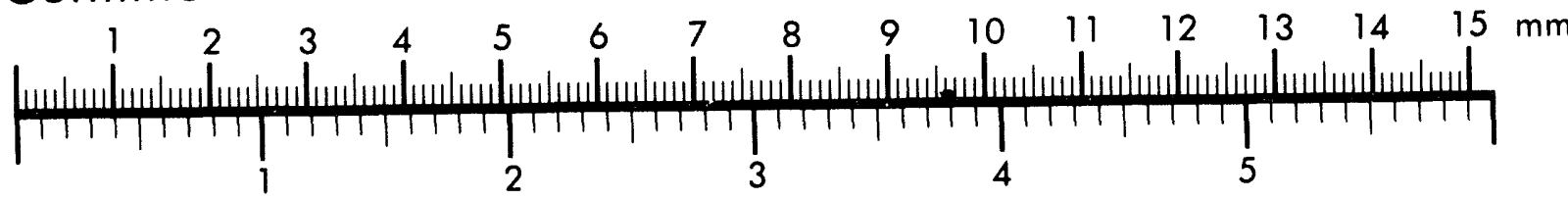

Inches
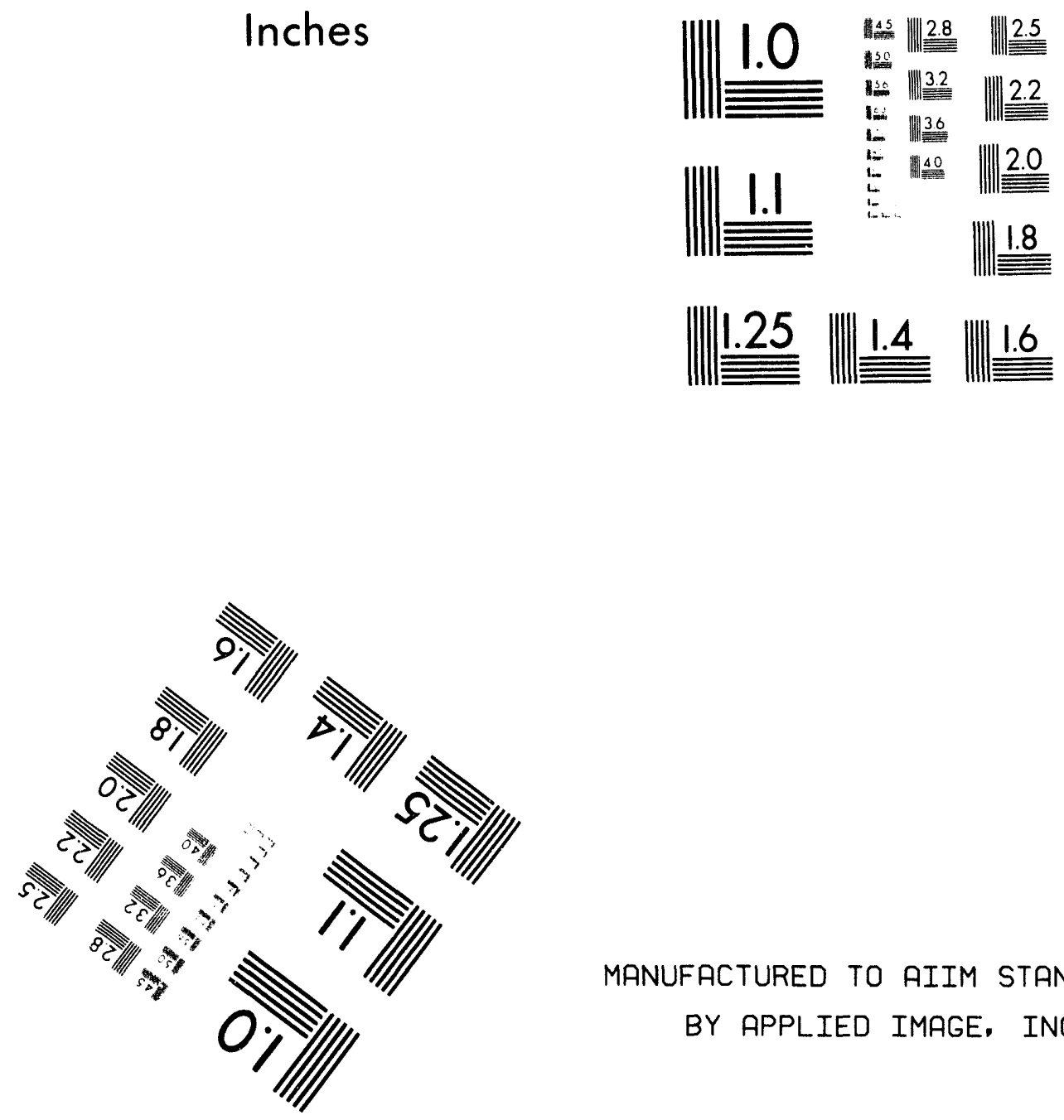

MANUFACTURED TO AIIM STANDARDS

BY APPLIED IMAGE, INC.

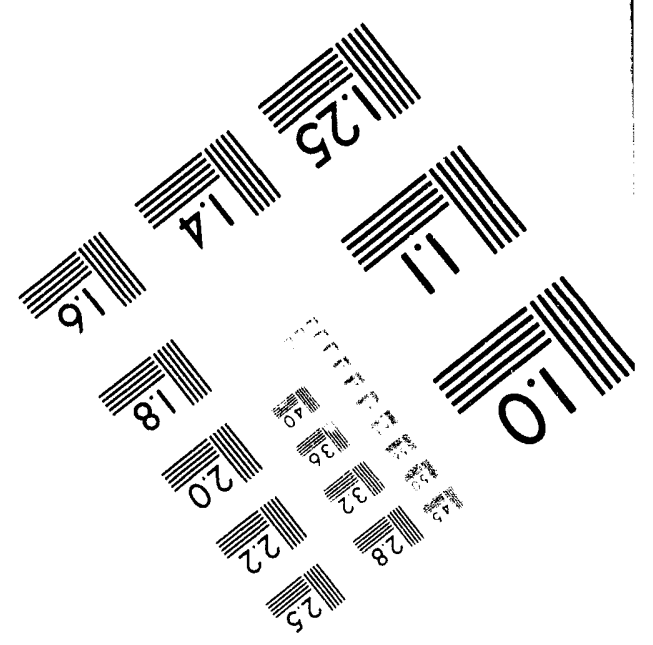



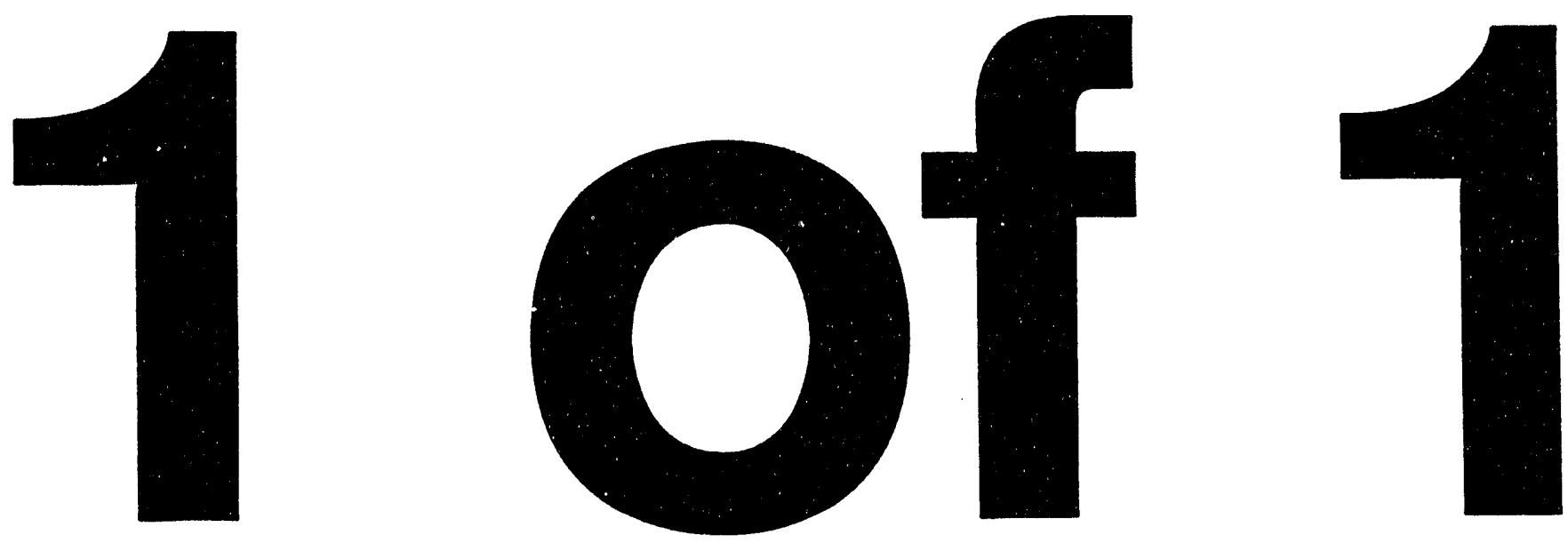


\section{ASSESSMENT OF COMBUSTION AND RELATED ISSUES IN THE DWPF AND ITP WASTE TANKS}

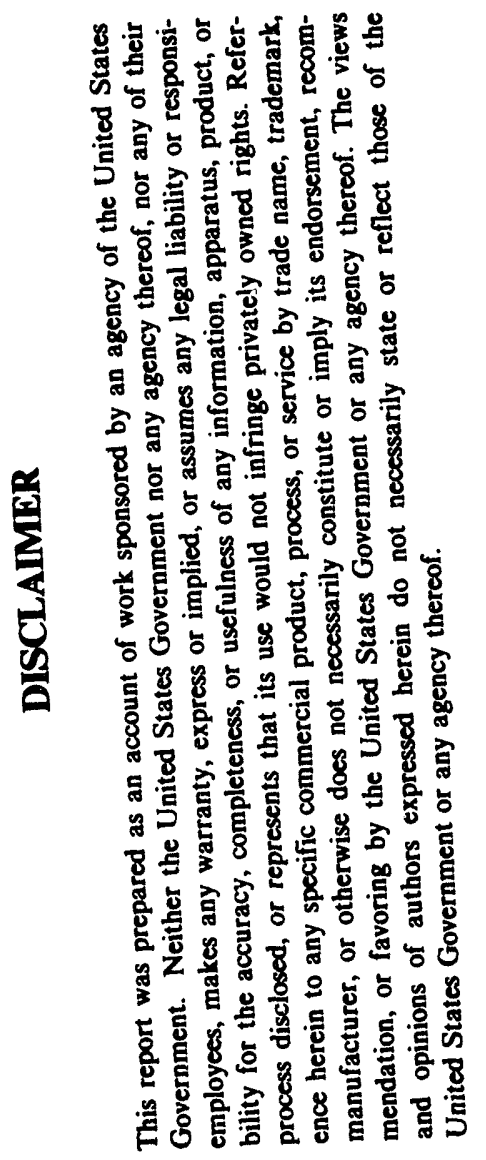

T. Ginsberg

April 1994

SAFETY AND RISK EVALUATION DIVISION

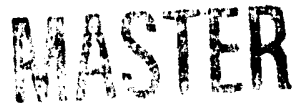

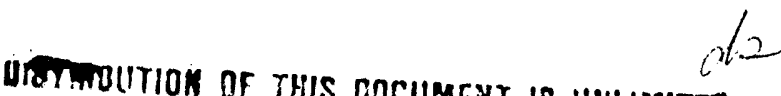




\title{
ASSESSMENT OF COMBUSTION AND RELATED ISSUES \\ IN THE DWPF AND ITP WASTE TANKS
}

\author{
T. Ginsberg \\ Brookhaven National Laboratory \\ Department of Advanced Technology \\ Upton, NY 11973
}

April 1994

Prepared for

U.S. Department of Energy

Washington, DC 20555

Contract No. DE-AC02-76CH00016 


\begin{abstract}
This report presents a review of the safety analyses described in the DWPF Safety Analysis Report, the combustion analysis of the ITP Tanks 48 and 49, and presents conclusions drawn from interviews with WSRC staff on issues related to accident analysis, in particular on issues related to combustion phenomena. The major sbjectives of this report are to clarify the issues related to the modes of combustion and expected loads on process vessels and structures and, in addition, to offer recommendations which would improve the defense-in-depth posture of the DWPF.
\end{abstract}




\section{TABLE OF CONTENTS}

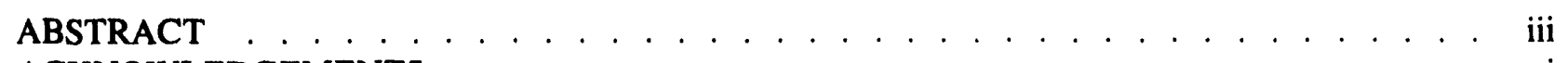

ACKNOWLEDGEMENTS . . . . . . . . . . . . . . . . . . . . . . . . . . . . . . . vi

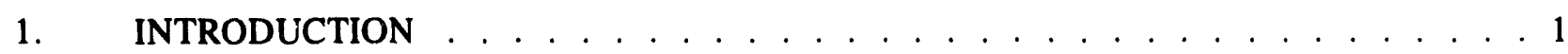

2. OVERALL VIEW OF THE DWPF PRA . . . . . . . . . . . . . . . . . . . . . 1

3. ASSESSMENT OF COMBUSTION PHENOMENA IN THE DWPF . . . . . . . . . . . 1

3.1 Introductory Remarks . . . . . . . . . . . . . . . . . . . . . . . . . . . . 1

3.2 Internal Events . . . . . . . . . . . . . . . . . . . . . . . . . . 2

3.2 WSRC Analysis . . . . . . . . . . . . . . . . . . . . . . . . . . . . . . 2

3.2 Assessment. . . . . . . . . . . . . . . . . . . . . . . . . . . 2

3.2.3 Recominendations . . . . . . . . . . . . . . . . . . . . . . . . . 4

3.3 Seismic Events . . . . . . . . . . . . . . . . . . . . . . . . . . 5

3.3.1 WSRC Analysis. . . . . . . . . . . . . . . . . . . . . . . 5

3.3.2 Assessment. . . . . . . . . . . . . . . . . . . . . 6

3.3.3 Recommendations. . . . . . . . . . . . . . . . . . . . . . . . . . . .8

3.4 Summary. . . . . . . . . . . . . . . . . . . . . . . . . . . . . . . . . 9

3.4.1 Analysis Recommendations. . . . . . . . . . . . . . . . . . . . . . . . . . . . 10

3.4.2 Design Backfit Recommendations . . . . . . . . . . . . . . . . . . . . . . . . . . . 12

4. ASSESSMENT OF COMBUSTION PHENOMENA IN THE ITP WASTE

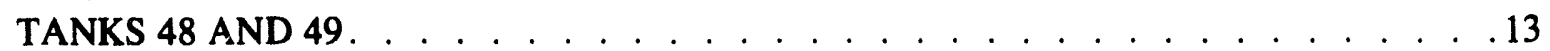

4.1 Introduction . . . . . . . . . . . . . . . . . . . . 13

4.2 Mode of Combustion . . . . . . . . . . . . . . . . . . . . . . . . . . . . . . . 14

4.3 Deflagration Pressure Rise . . . . . . . . . . . . . . . . . . . . . . . . . . . . . . 14

4.4 Waste Tank Failure Mode and Radiological Aerosol Generation . . . . . . . . . . . . . 15

4.5 Recommendations. . . . . . . . . . . . . . . . . . . . . . . . 15

5. REFERENCES . . . . . . . . . . . . . . . . . . . . 15

APPENDIX A: $\quad$ PRELIMINARY REVIEW OF THE DWPF SAR FROM THE POINT OF VIEW OF RADIONUCLIDE RELEASE FROM THE PLANT . . . . A-1

APPENDIX B: $\quad$ DWPF QUESTIONS . . . . . . . . . . . . . . . . . . . . . . B-1

APPENDIX C: $\quad$ CELL COVER LIFTING DUE TO AN INTERNAL EXPLOSION. . . . C-1

APPENDIX D: $\quad$ ITP QUESTIONS AND ANSWERS . . . . . . . . . . . . . . . . D-1 


\section{ACKNOWLEDGEMENTS}

The author gratefully acknowledges the many helpful discussions related to DWPF safety which involved Mr. Frank Chen and Mr. John Psaras of the DOE Office of Environment, Safety and Health. Mr. Pete Matonis, of EG\&G Idaho, Inc., provided an excellent review of the report. The author is also appreciative of the help of Ms. Jean Frejka, who prepared this manuscript for publication. 


\section{INTRODUCTION}

This report presents a review of the safety analyses described in the DWPF Safety Analysis Report (SAR) [1], the combustion analysis of the ITP Tanks 48 and 49 [2], and presents conclusions drawn from interviews with WSRC staff on issues related to accident analysis, in particular on issues related to combustion phenomena. The major objectives of this report are to clarify the issues related to the modes of combustion and expected loads on structures and, in addition, to offer recommendations which would improve the defense-in-depth posture of the DWPF.

Section 2 provides an overall view of the results of the DWPF Probabilistic Risk Assessment (PRA), presented in the SAR. Section 3 is an assessment of combustion phenomena in the DWPF process vessels and process cells and contains this author's recommendations. Section 4 discusses the combustion issues related to the ITP Tanks 48 and 49 and provides recommendations. A summary is presented in Section 5.

\section{OVERALL VIEW OF THE DWPF PRA}

Appendix A contains a copy of a preliminary review of the DWPF SAR which was submitted to $\mathrm{DOE} / \mathrm{EH}$ on October 6,1993 . In that review, an overview was provided of the facility performance from the PRA perspective of the SAR, as represented by Table A-1 of Appendix A. It was apparent that once the first line of defense against radiological release was breached, the process vessels provided no barrier against release and, for external events, decontamination by the ventilation and sand filter bed was assumed unavailable. For internal events, minimal risk was predicted as a result of the assumption of active ventilation and effective sand bed decontamination. Appendix B contains a list of questions, based upon a preliminary review, which were forwarded to DOE/EH in October 1993.

In the followup review presented here, a closer examination is made of the questions related to combustion modes and loads, process vessel integrity, propagation of damage within the facility and the extent of radiological aerosol release and decontamination. The results of the additional analysis are discussed in Section 3 below.

\section{ASSESSMENT OF COMBUSTION PHENOMENA IN THE DWPF}

\subsection{Introductory Remarks}

Combustion phenomena arise in the process vessels following an initiating event which leads to loss of purge flows to the vapor space of the vessels. Combustible gas subsequently begins to accumulate in the vessel vapor spaces, either hydrogen from radiolysis, or from benzene evaporation. An ignition source is assumed to be available within the vessel, initiating combustion at some time following the initiating event. WSRC bases its evaluations on the assumption that combustion is initiated with stoichiometric mixtures in the vessel vapor spaces.

During Operating Modes A and B (both involving radioactive sludge and non-radioactive simulated precipitate), all of the radioactive inventory in the Canyon will reside in the Chemical Processing Cell (CPC), in particular in the SME, SRAT and MFT vessels, with an additional small quantity in the SMECT vessel. The Salt Processing Cell (SPC) will not contain radioactive inventory in Modes A and B. During Mode $C$ (involving radioactive sludge and radioactive precipitate), the PR and PRFT vessels will contain radioactive inventory. In order to release quantities of radiation from the DWPF 
during Modes A and B, therefore, one or more of the CPC vessels must be breached. Furthermore, in order that a "significant" quantity of radiation be suspended and available for transport out of the Canyon, an efficient mode of liquid aerosol generation must be postulated. According to the WSRC model, process vessel "explosions" leads to "explosive aerosolization" of the vessel liquid. This postulated mechanism of aerosol generation is responsible for the largest calculated releases. If a vessel simply "spills" its contents into the CPC, the available mechanisms which could release radiation would do so only at very small rates and the total releases are small.

Table 1 describes three important accident scenarios in which combustion events lead to radioactive releases from the DWPF. These scenarios are representative, and are used here to identify the major assumptions which influence the predicted releases and, in addition, to identify weaknesses in the DWPF safety analysis and uncertainties in phenomenology which, it is recommended, WSRC should address in future work.

\subsection{Internal Events}

\subsubsection{WSRC Analysis}

The internal events analyzed by WSRC, of which Scenario 1 is an important example, are all strongly influenced by the presence and assumed functionality of the sand filter bed. In order to release a significant quantity of radiation from the DWPF, one of the CPC vessels containing radioactive liquid inventory must be breached and, in addition, a mechanism must be postulated to defeat the decontamination function of the sand filter bed.

In Scenario 1, a combustion event in the SPC PR process vessel is postulated to lead to PR vessel failure, setting off a chain of propagating events. During Operational Modes A and B, the PR vessel will contain no radioactive inventory and, as a result, the extent of aerosolization of the vessel's liquid contents which would take place following vessel failure is not crucial. The failure of the PR vessel is assumed to lead to generation of vessel fragments which results in breach of the OECT vessel containing benzene. The benzene release to the Salt Cell is presumed to result in a benzene detonation in the SPC, followed by breach of the Vitrification Building roof by a cell cover missile, failure of the wall separating the SPC and CPC, followed by damage to and spillage of the contents of the CPC vessels, some of which contain radioactive inventory. This scenario results in minimal consequences, however, because of two major assumptions: (i) the assumed spillage of liquid leads to minimal radiation aerosol release by weak dispersal mechanisms accompanying a spill, and (ii) the continued operation of ventilation system fans keeps gases and suspended aerosol passing through the sand beds, decontaminating the released gases, despite the postulated presence of a hole in the Vitrification Building roof.

\subsubsection{Assessment}

The WSRC project assumes that upon ignition, combustion is initiated in the mode of a gaseous detonation in the vapor space of the process vessel under consideration, in this case the PR vessel. The vessel is assumed to fail catastrophically, producing fragments which act as missiles. Since no radionuclide inventory is present during Operational Modes $\mathrm{A}$ and $\mathrm{B}$, the mechanisms of, and extent of, aerosolization of vessel liquid content which would accompany vessel failure is not an issue. The mechanics of vessel failure are not addressed by WSRC. The project assumes catastrophic failure of the vessel and the generation of high-velocity vessel fragments resulting from the explosion. 
It is this author's judgement is that in the absence of energetic electrical sources within the process vessels which could initiate a detonation directly, the likely mode of combustion in the process vessels under stoichiometric gas mixture conditions is that of a deflagration. The vessels are relatively small (approximately $15 \mathrm{ft}$. diameter), lack arrays of turbulence-generating equipment in their vapor spaces and, as a consequence, flame acceleration and deflagration-to-detonation transition is unlikely. The vessels, however, have piping runs attached to them which may be filled with detonable gas mixture. If the gas is ignited, the piping runs may be long enough to cause a transition to detonation within them. The detonation could, in principle, be transmitted from the pipe into a detonable mixture within the process vessel, leading to a detonation within the vessel. This possibility can be designed out based upon "critical tube" size detonation transmission criteria found in the literature [3].

Even, as suggested above, if detonations are not likely in the process vessels, the deflagration mode of combustion of stcichiometric mixtures of either hydrogen or benzene will generate pressures several times the design pressure of the process vessels. The process vessel design pressure is about 30 psia [Ref. 1, p. 9.4.22) while the adiabatic, constant volume pressure for stoichiometric hydrogen-air is 118 psia, while for stoichiometric benzene-air the pressure is 154 psia. Such pressures resulting from deflagrations in the process vessels will likely pose a serious challenge to their integrity. Vessel failure appears likely, but either stress calculations or hydrostatic testing are needed to confirm this judgement.

The analysis of Scenario 1 assumes that the PR vessel fails catastrophically, produces high-velocity fragments which puncture the OECT vessel which contains benzene. This author's judgement is that this assumption, made with no supporting arguments, may prove to be overly conservative. If the conclusion would turn out to be that high-velocity fragments which could lead to damage propagation are not likely, then the accident progression would terminate with PR vessel failure, and no propagation to the CPC cells would be possible. The mode of vessel failure should, it is felt, be dealt with mechanistically, rather than by assumption. Detailed structural analyses should be performed to determine the mode of vessel failure, and the likelihood of generation of high-velocity fragments. This analysis should be subject to peer review and, perhaps, be supplemented with experiments to verify model predictions and vessel failure conditions. If the conclusion is reached that PR vessel fragments will indeed puncture the OECT vessel, then it is recommended a shield be designed and positioned such that rupture of the OECT vessel is rendered highly unlikely.

In the event that the OECT vessel is breached, benzene spilled, evaporated in the SPC gas space to form a stoichiometric mixture and ignited, the DWPF SAR assumes that a vapor phase detonation will occur in the SPC. The mode of combustion is, however, somewhat uncertain. The SPC is a relatively large room, with much empty space, but with considerable equipment packed closely down around floor level. The equipment would act as turbulence generators which would enhance flame acceleration. Ignition would cause initiation of a deflagration. The issue here is whether flame acceleration to a transition to detonation is conceivable in such a space, given a stoichiometric mixture of either hydrogen or benzene and air. Experiments on the scale, and in geometries similar to the Salt Processing Cell have not been carried out, and computer models of flame acceleration within spaces characterized by complex boundary conditions are developmental. Experimental data from experiments performed in channel-like geometries which contain obstacles to simulate structural components, indicate that stoichiometric mixtures of hydrogen-air are prone to transition to detonation in relatively short lengths of obstacle-filled channels [4]. On the other hand, experiments in large, unconfined volumes with no obstacles have not led to observations of transition to detonation [5]. No such data are available for benzene-air mixtures. While the SPC volume is unconfined, the presence of significant structure suggests the possibility of turbulence-enhanced flame acceleration. Whether or not the acceleration would be adequate to approach the regime of highly accelerated flames, dynamic loads 
and transition to detonation is an open question. This author's judgement is that a transition to detonation cannot be precluded with confidence.

The DWPF SAR assumes that if a detonation in the SPC occurs, then a cell cover would be launched upwards as a projectile towards the concrete roof of the DWPF, and would penetrate the concrete, creating an opening to the environment. BNL has modeled this scenario, and the analysis and results are presented in Appendix C. The calculation, conservative on some respects, was performed for both an assumed detonation, and an assumed deflagration. Cell pressure-time histories were computed for both combustion modes, and were applied to a projectile calculation for a typical cell cover. The velocity of a cell cover at impact with the concrete roof of the DWPF was computed, and used as input to a correlation of projectile penetration thicknesses for reinforced concrete barriers. The results of the calculations suggest that a cell cover could be accelerated to sufficiently high velocity so that upon impact with the roof it could, based on conservative assumptions, penetrate the concrete roof. The differences in response for a deflagration versus a detonation were not decisive. This result arises because of the very large frontal area of a cell cover, from the large pressures (deflagration or detonation) which are sustained for the tens of milliseconds necessary to impart the required impulse to the cover. There are several conservative assumptions involved in the calculation, but they are difficult to remove with confidence. The DWPF SAR assumption regarding penetration of the concrete roof, therefore, cannot be simply ruled out based upon an idealized calculational model. Thus, one must consider the consequences of an opening in the roof of the building on radiological aerosol release.

The SAR analysis of Scenario 1 assumes that, despite the hole in the roof of the DWPF, the ventilation fans continue to function, and ensures exhaust of any gases containing radioactive aerosol through the sand filter bed. As long as fans are operational, no outflow through the roof occurs. Air, instead, is sucked into the Canyon from the outside. It is suggested that this assumption must be futher assessed to determine whether the scrubbing effectiveness of the filters is affected by the additional flow path provided by the hole in the roof.

The SAR analysis assumes that upon a benzene-air detonation in the SPC, the wall separating the SPC and CPC undergoes an unspecified failure, and causes missile fragments to puncture the vessels in the CPC and to, thereby, spill their contents. None of these assumptions have been justified by calculation. Assumed failure of the wall to result in puncture of the vessels may be overly conservative. On the other hand, if a fragment does penetrate the vessel and the vessel contains a sensitive combustible mixture, then it would seem that friction-generated spark ignition would be possible as a result of impacting fragments with interior metal surfaces. Combustion, therefore, could be initiated. If the SAR logic is followed, then combustion would lead to a vessel detonation, explosive aerosolization and radioactive releases for this scenario which would be larger than presented in the SAR. This variant of the basic SAR scenario has not been considered by WSRC. The WSRC treatment is not, in this respect, conservative.

\subsubsection{Recommendations}

The WSRC SAR methodology contains many assumptions which, in some cases, may be overly conservative and, in other cases, neglect factors which could lead to greater risk than currently reported. Because the assumptions are not uniformly conservative, as shown in Table 1, it cannot be argued that the results are conservative. It is recommended that the next version of the DWPF SAR be based upon best judgement analysis, based upon the best models and engineering judgement that is available. This should provide a clearer picture of risks and a better idea of margins to significant radionuclide release. Specific recommendations follow: 
(1) Perform structural calculations directed toward prediction of the response of the process vessels to postulated deflagrations and detonations. Determine the failure pressure, the mode of vessel failure, and the likelihood of vessel fragmentation, missile generation and propagation of this sequence to the next stage. Because of the increasing complexity of the events which follow, this step is most important. (For the Mode $C$ operations, the mechanism of liquid aerosolization of radioactive inventory in the SPC vessels will become important. This will be discussed further in Section 3.3).

(2) If high-velocity missile fragments cannot be precluded, it is recommend that a missile shield be designed for the tanks in the SPC containing benzene.

(3) It is recommended that a benzene spill be precluded by design. If, however, a benzene spill cannot be precluded, either by calculation based upon the existing design or by design changes, verify the continued decontamination effectiveness of the sand bed filter in the presence of a hole in the roof of the DWPF generated by penetration of a cell cover projectile.

(4) If a benzene-air detonation cannot be precluded, provide mechanistic analysis to support the assumption that the SPC/CPC wall would fail and launch missiles in the direction of the CPC tanks.

(5) If analysis demonstrates that SPC/CPC wall would fail and launch fragments, then provide design changes which would either prevent the wall from failing in such a manner, or which would prevent the CPC vessels from puncturing.

(6) If high-velocity missile fragments cannot be shown to preclude puncturing the CPC tanks, provide analysis of the scenario in which friction-generated spark ignition of combustible gases in the vessel vapor spaces results in combustion in these tanks. Is such spark ignition possible? What is the effect of combustion in these tanks on the extent of radionuclide release?

\subsection{Seismic Events}

\subsubsection{WSRC Analysis}

The seismic event sequences analyzed by WSRC, of which Scenarios 2 and 3 in Table 1 are the most severe, are significantly influenced by the assumption that following an earthquake the Vitrification Building offers no effective decontamination function to suspended aerosol. Unspecified pathways are assumed to be available for direct release of suspended radioactivity to the environment. The analysis assumes that any radioactive aerosol released from the process vessels would see a direct pathway to the environment. This assumption imparts a dominant role to the sequence of phenomena involved in vessel combustion, failure and aerosol production and implies that, for the seismic events, a good understanding of these phenomena are crucial for meaningful estimation of contribution to risk. As is discussed below, such an understanding does not, in this author's opinion, currently exist.

Scenarios 2 and 3 listed in Table 3 are, to a point, similar sequences. Scenario 2 is initiated with combustion events in two CPC process vessels, the PRBT and the MFT tanks. It is important to note that only one of the two vessels, the MFT, contains radioactive inventory. The combustion event is assumed to be a detonation [6], leading to energetic vessel failure, explosive aerosolization of the radioactive liquid contents of the MFT vessel, and overpressurization of the CPC cell. The quantity of 
radioactive aerosol produced is computed using a blast wave fragmentation correlation taken from the literature'. The overpressurization of the cell lifts the cell covers, which fall back into the cell and breach the remaining process vessels in the CPC cell. These vessels, however, are postulated to simply spill their contents on to the floor of the CPC cell, with little resulting aerosolization. The net result of all of these vessel failures is that only one of them actually leads to suspension of significant radioactive aerosol in the DWPF. The aerosol is released from the DWPF with little decontamination.

Scenario 3 is more severe in terms of damage to the DWPF building. In this case, one or both of the OE/OECT tanks in the SPC is assumed to fail along with the explosions of the CPC PRBT/MFT vessels, as a result of the seismic event, spilling benzene into the SPC. The OE/OECT vessels are assumed to fail as a result of a judgement of their fragility in the instance of a design basis earthquake. In his case, as opposed to Scenario 2, the CPC cell covers are not assumed to lift, fall back and damage the remaining CPC vessels. The benzene spill is postulated to lead to development of a combustible mixture within the Salt Cell which ignites under stoichiometric benzene-air mixture conditions and and burns as a detonation within the cell. This detonation then is assumed to lead to failure of the PR and PRFT process vessels within the SPC. During Operating Modes A and B, these vessels contain no radioactive inventory, so their failure does not contribute to the severity of the postulated sequence. The detonation in the SPC leads to acceleration of a cell cover in the direction of the concrete roof of the DWPF. The cover is assumed to penetrate the roof, leaving a hole and a pathway to the environment. Aerosol suspended from the MFT vessel combustion event and vessel failure is released from the DWPF building. The analysis assumes that the ventilation is off and that aerosol is released to the environment without decontamination, with or without the breach of the DWPF roof. The breach would play an important role if the building were assumed to be relatively "tight" after the seismic event.

\subsubsection{Assessment}

The radiation releases in both Scenarios 2 and 3 follow from a series of assumptions which are made to characterize the consequenres of postulated combustion events in the CPC PRBT and MFT vessels, as summarized in Table 1 . The significant radiation release arises as a result of the assumed detonation of a stoichiometric hydrogen-air mixture in the MFT, followed by energetic vessel failure and explosive fragmentation of its liquid contents. As in the case discussed in Section 3.2.2, this author's judgement here is that ignition would lead to a deflagration, not a detonation. However, as previously discussed, the deflagration pressure rise would likely lead to pressures well-above the design pressure of the vessel, and energetic vessel failure is possible. The SAR assumes, however, that given this sequence of events, that the liquid contents of the MFT would undergo "explosive aerosolization," modeled using blast wave fragmentation correlations from the literature, as described in Reference 7.

The aerosolization correlations used were obtained from highly idealized experiments in which the sample material formed either a spherical or cylindrical annulus around a centrally located charge of explosive. This geometry was chosen in the experiments in order to optimize the fragmentation process. The Steindler-Seefeldt model for "explosive aerosolization" approach to modeling the extent of aerosol generation is, as mentioned above, fundamentally not applicable to the process vessel failure scenario. Use of the approach as "conservative" is, moreover, also invalid and potentially misleading. The basic correlating parameter, the ratio of mass of dispersable liquid to the TNT mass equivalent of the combustible gas, was varied up to approximately 10 in the experiments on which the method is based. A value of 1000 is characteristic of a typical process vessel. Thus, even if one were to accept (wrongly) the method as being conservative, an extrapolation of the experimental correlating variable by two orders of magnitude is required. This extrapolation, moreover, is in the direction of decreasing the respirable fraction of airborne debris. The use of the Steindler-Seefeldt correlation is 
fraught with uncertainties. The data presented in the original paper (used by the authors, but the experiments were not their own) are inadequate to draw conclusions regarding uncertainties. Any use of this method should have some associated judgement made of the uncertainty range.

The configuration of the experiments differs markedly from the configuration of a DWPF process vessel, which is a tank of liquid with an overlying combustible gas which undergoes a deflagration (or even a detonation). In this case, the deflagration pressure rise in the vessel vapor space would likely fail the vessel. The mechanism, location and characteristics of thie failure process would determine the extent of radiological aerosol generation. If the vessel fails in the gas space above the liquid, then the aerosol produced would likely be the result of entrainment from the surface of the liquid pool. If, on the other hand, the vessel fails below the liquid surface, the liquid would be forced through any openings created by the failure mechanism. The aerosolization process would accompany the flow of the liquid through availaole openings in the vessel, created by the failure process. The mechanism of aerosol production would likely resemble that characteristic of spray nozzles. Use of the explosive fragmentation methods of Reference 7 is inappropriate for this vessel failure mechanism. The analysis should focus on a better understanding of vessel failure and the impact of the mechanism of failure on the liquid fragmentation processes. The fraction of respirable aerosol generated should be computed on the basis of models of the appropriate aerosol generation mechanisms.

In Scenario 2, the MFT vessel failure is accompanied by CPC cell pressurization, cell cover lifting, and falling on the remaining vessels in the CPC, failing them and causing their liquid contents to spill. This propagating sequence of events, although undesirable from a basic safety design point of view, does not lead to significant consequences in the SAR, since the assumption is made that the liquid simply spills out of the tanks, with no accompanying combustion and energetic liquid dispersal. If the CPC tanks contain combustible gas in their vapor spaces at the time they are being destroyed by falling cell covers, then the question must be asked as to whether combustion can be initiated during this time period. Perhaps friction-generated sparks, static discharges, or other electrical discharges could potentially initiate combustion in the vessels. This possibility was not considered in the SAR. If ignition is possible, then a deflagration in the vapor spaces could lead to vessel failure. If one then follows the SAR logic, the combustion process then would lead to energetic vessel failure and explosive aerosolization of the CPC process vessel radiological inventory and releases which would be 3-4 times larger than predicted in the current SAR. This propagating scenario, which has the potential for releasing more radiation than predicted in the SAR, must be carefully considered mechanistically. A key element in this scenario is the same one as described in the previous paragraph, the extent of aerosol generation during a vessel combustion event which leac's to energetic vessel failure.

In contrast to Scenario 2, Scenario 3 does not consider (it is not specifically stated) cell cover displacement following failure of the MFT vessel. WSRC should consider this possibility.

Scenario 3 postulates seismic failure of the OE/OECT vessel(s), leading to a benzene spill in the SPC. Ignition of an assumed stoichiometric benzene-air mixture in the SPC is presumed to lead to a detonation in the SPC. As discussed in Section 3.2.2 above, the judgement as to whether a deflagration or detonation would be the mode of combustion is a difficult one. The evidence is not conclusive and, it is believed that a detonation cannot be precluded. The benzene combustion process is predicted by the SAR to lead to the launch of a cell cover in the direction of the DWPF roof and, additionally, to breach, by unspecified mechanisms, both the PR and PRFT vessels in the SPC. As discussed in Section 3.2.2, the BNL analysis of the cell cover launch leads to the conclusion that penetration of the roof with a cell cover is possible on the basis of an analysis which is, in part, conservative. Additionally, this conclusion applies whether the combustion mode is a detonation or a deflagration, although the margins to failure of the roof are somewhat different. The physical reason 
for this result is that the deflagration pressure is sufficiently large and is sustained for a sufficiently long time, so as to impart sufficient impulse to the cell covers to lead to velocities which are large enough to challenge the concrete roof. In this sense, therefore, the mode of combustion, although uncertain, is not decisive. Given a benzene spill, therefore, and the assumption of ignition of a stoichiometric benzene-air mixture, the roof could be breached by a cell cover and a path to the environment would be created. This result is based upon some conservative assumptions, but these conservatisms are difficult to remove without extremely difficult calculations or engineering judgements.

Based on the assumptions of the SAR, the breach of the DWPF roof would have no impact on radiological release from the DWPF during a seismic event, since the building is assumed to be "leaky" following an earthquake. The SAR assumes little decontamination following an earthquake, with ventilation off and unspecified flows and pathways available to carry radiological aerosol out of the building. As a result, the appearance of an additional pathway in the form of a breach in the building has little or no bearing in the results. There appears to be no analysis which leads WSRC to conclude that the DWPF is, indeed, "leaky" following an earthquake, in terms of its ability to retain suspended aerosol. If the building is not as open as assumed, however, then the breach of the building would be a significant factor.

The Scenario 3 accident would continue with the benzene detonation causing failure by unspecified mechanisms of the PR and PRFT vessels, which are then postulated to be breached and to spill their contents. In Modes A and B operations, these two vessels contain no radioactive inventory. As a result, for these modes, no additional releases would result from the additional vessel damage. For Mode $\mathrm{C}$, these vessels could potentially release their radionuclide inventories. The question arises, as it did above, as to whether the vessels would benignly spill or, alternatively, whether combustion would be initiated during the breach process, leading to possible explosive aerosolization of their liquid inventories. These questions of mode of vessel failure and potential for either benign spill or energetic failure and aerosolization must be resolved for a realistic estimate of risk, especially for Mode C.

In both Scenarios 2 and 3, the events begin with explosions in the CPC PRBT and MFT process vessels. Propagation, according to the SAR analysis, of the sequence to failure of additional vessels and failure of the DWPF roof as a result of cell cover displacement or launch as a missile. An additional propagation mechanism has not been considered by WSRC. The vent lines from the process vessels in the CPC are interconnected, and terminate in the Process Vessel Vent Header. If these lines were filled with combustible mixture, then it is conceivable that a combustion event which initiates in one vessel would propagate to the other vessels through this interconnected piping pathway. If we follow the SAR logic, combustion in the process vessels leads to a detonation, energetic vessel failure and explosive aerosolization of their liquid contents. This logic would lead to radiological releases larger than predicted in the SAR. This potential for propagation should be addressed by WSRC.

\subsubsection{Recommendations}

As in the case of the internal events, the WSRC seismic analysis contains many assumptions which, in some cases, may be overly conservative and, in other cases, neglect factors which could lead to greater risk than currently reported. Because the assumptions are not uniformly conservative, as shown in Table 1, it cannot be argued that the results are conservative. It is recommended that the next version of the DWPF SAR be based upon best judgement analysis, based upon the best models and engineering judgement that is available. This should provide a clearer picture of risks and a better idea of margins to significant radionuclide release. Specific recommendations follow: 
(1) The failure of process vessels containing radiological inventory is the major event which leads to radiological release. The series of events beginning with ignition of a combustible mixture in the vapor space, and including pressurization, vessel failure, and aerosolization of liquid radiological inventory, needs to be better understood. Structural calculations should be directed towards prediction of the response of the process vessels to postulated deflagrations and detonations. The failure mode should be identified, and provide insights to judgements concerning the mechanisms of aerosolization of vessel liquid inventory. Careful consideration should be given as to the appropriateness of the use of the Steindler-Seefeldt methods of Reference 7 for calculating the aerosol release from a vapor-space combustion event in a process vessel.

(2) The assumption that the SPC OE/OECT process vessels would fail and spill their benzene contents in the event of a design basis earthquake should be verified by analysis.

(3) If it is confirmed that the OE/OECT vessels would spill their benzene as a result of an earthquake, a design fix should be sought which will reduce significantly the likelihood of such a failure.

(4) The DWPF building is assumed to open flow paths to the environment and to be incapable of retaining radiological aerosol following a design basis earthquake. This assumption should be verified by analysis.

(5) Following an initiating explosion in a process vessel, cell cover displacement is assumed to lead to covers falling on additional vessels and breaching them, causing their liquid contents to spill without combustion of vessel gas mixture and, therefore, without energetic vessel failure and explosive aerosolization. This set of assumptions should be justified by analysis, since some additional vessels contain radiological inventory which, if released, could increase risks. (During the process of vessel breach by falling cell covers, can ignition occur in the vessel vapor spaces, as a result of friction-generated sparks, or potential electrical discharges associated with the disruptive events?)

(6) The potential for propagation of combustion from one process vessel to others through the vent lines should be addressed. The likelihood of increased radiological release should be considered.

\subsection{Summary}

The WSRC SAR description of the DWPF presents a picture of a facility which is vulnerable to radionuclide release to the environment once the first line of defense against release has failed. Since a release could occur upon breach of a process vessel containing radionuclides, the first line of defense is the purge and vent system which is designed to prevent the buildup of combustible hydrogen-air or benzene-air mixtures in the process vessel vapor spaces. Once this system fails, combustion in at least one vessel is postulated. The process vessels were not designed, as they would be if today's safety standards were to apply, to withstand a pressure load resulting from a deflagration. A further system vulnerability which is revealed by the SAR is that a single vessel failure leads to damage propagation to adjacent vessels and, in some instances, to damage to the facility itself. 
Based upon the SAR methodology, if a combustible mixture develops in the vessel, combustion is assumed. If the gas mixture is stoichiometric, which is assumed by WSRC, vessel failure becomes very likely, as a result of the low design pressure of the process vessels. Vessel failure is accompanied by release of the radioactive liquid to the process cell. At this point a release to the environment is assured, the only questions being how many vessels fail, how much radiation is suspended in the cell, and how much of this is transported out of the DWPF building to the environment.

The risks to the public, site personnel, and co-located workers depend on the magnitude of the radiation release. Analysis of the assumptions and models used to provide estimates of the extent of radiation release lead this author to the conclusion that large uncertainties in the magnitude of radionuclide release exist at the present time, and that, as a consequence, the risk estimates are likewise quite uncertain. Some assumptions have been made and models have been used for dominant physical processes which are overly conservative. On the other hand, other assumptions and models have been implemented which very likely provide underestimates of radionuclide release and risk. The risk profile for the DWPF, therefore, cannot be categorized either as conservative or best estimate. Additional work must be performed by WSRC in order to provide a risk profile for the plant which is credible.

It is recommend that the next version of the DWPF SAR be based upon best estimate engineering analysis, complemented by best engineering judgement when necessary. This should provide a better understanding of the margins to significant radionuclide release and a clearer picture of risks to the public, co-located worker and DWPF personnel. Additionally, analysis has suggested several potential ideas for some plant hardware safety features which are recommended for implementation. Recommendations for analysis and for design modifications are summarized below.

\subsubsection{Analysis Recommendations}

\section{Process Vessel Failure and Aerosol Production Mechanisms}

The process vessel combustion, pressure loading and potential failure sequence is the area in most need of better phenomenological understanding, since this is the portion of the accident scenarios which both initiates the radiological release and, in addition, leads to propagation of further damage to the facility.

The quantity of radiological aerosol suspended in the process cells is intimately tied to the mode of vessel failure. SAR radiological aerosol releases are computed based upon experiments which do not appropriately simulate aerosol releases from a vessel which is in an undefined failure mode, configured with a pressurized gas overlying the liquid which is undergoing fragmentation. The aerosol production mechanism is very likely a hydrodynamic one, differing significantly from a phenomenological point of view from the prosess of "explosive aerosolization." It is recommended that this entire sequence of events be considered more carefully, with the objectives of defining the likely modes of vessel failure, and developing an understanding of the dominant mechanisms of liquid aerosol production. All potential mechanisms of vessel failure should be considered, including potential direct damage to the process vessels by loads imparted by the earthquake.

The mode of vessel loading and potential for energetic failure also influences the propagation of damage to other process vessels and to the integrity of the facility itself. The structural response of the process vessels to deflagration and detonation pressure loading should be assessed, and the potential for missile generation resulting from vessel failure should be evaluated. The potential for damage to other vessels from such missile fragments should be analyzed. 
One reason that the computed radiological releases predicted in the SAR are as low as they are because vessels which are assumed to be breached by vessel fragments or cell covers, are assumed to release their liquid contents by a benign spill. Combustible gases in the vessel vapor spaces are assumed not to ignite and undergo combustion. As a result, these breached vessels do not undergo energetic failure and explosive aerosolization of the liquid contents does not occur. Consequently, the radiological releases from these vessel breaches are quite small. It is suggested in Sections 3.2 and 3.3 that the possibility for ignition during these vessel breach events must be carefully considered. Potential ignition sources are possible due to friction from impacting fragments, and electrical sources which could present themselves during the disruptive events. If the breached vessels should fail explosively and aerosolize their liquid contents based upon the SAR methodology, then radiological releases would be larger than predicted in the SAR. It is recommended that the potential for combustion during the vessel breach process resulting from vessel fragments and falling cell covers be assessed, and the consequences considered.

\section{Damage Propagation Potential}

The assumptions made in the SAR have led to the result that an explosion in one process vessel can iead to damage propagation to additional process vessel failures and, in addition, to possible damage to the facility itself (the roof of the DWPF). The feature of damage propagation is not a desirable feature of a chemical processing plant, even if the initiating event is unlikely. Defense-in-depth is desirable. As indicated above, the assumptions may be overly conservative and, perhaps, the potential for propagation may not be as real as we are led to believe. Further analysis should help clarify the question of potential for damage propagation.

An additional mechanism for damage propagation has been identified. The vent lines from the process vessels in the CPC are interconnected, and terminate in the Process Vessel Vent Header (PVVH). If these lines were filled with combustible mixture, then it is conceivable that a combustion event which initiates in one vessel would propagate to the other vessels through this interconnected piping pathway.

Following the SAR logic, combustion in the process vessels leads to a detonation, energetic vessel failure and explosive aerosolization of their liquid contents. This logic would lead to radiological releases larger than predicted in the SAR. WSRC should present its analysis of the PVVH and associated piping and this potential for propagation should be addressed.

\section{Decontamination Effectiveness and DWPE Building Retention Capability}

A major assumption which influences the low risk estimates from internal events is the effective decontamination presented by the ventilation system and the sand bed filters. Even with an assumed breach in the roof of the DWPF, the decontamination of suspended aerosol is sufficiently effective so as to lead to extremely small releases to the environment. The reliability of the ventilation system and sand bed filters should be assessed, especially if the scenario incorporating a breach in the roof is considered seriously.

In contrast, the conservative assumption is made that following a design basis earthquake the DWPF building would present unspecified leakage paths to the environment. The DWPF building is assumed incapable of retaining suspended aerosol, and would present no effective decontamination to suspended aerosol. This assumption leads directly to substantial radionuclide releases from the plant. The assumption may be overly conservative, and could be giving mistaken impressions about the potential for substantial releases from the plant. WSRC should provide analyses, structural or otherwise, which 
demonstrates where the potential leakage paths are located, and how they were created by the design basis earthquake.

\subsubsection{Design Backfit Recommendations}

A number of potential design fixes have suggested themselves during the course of this analysis. As a general principle, plant hardware modifications are preferable to more detailed analysis, especially when the analysis uncertainties are large. A general recommendation is that WSRC search for potential additions or modifications to the plant hardware which has as the goal the reduction of the likelihood of damage propagation from a combustion event in one vessel to either other vessels or to the facility itself. The following specific recommendations are made for consideration.

\section{Process Vessel Venting}

The most basic concern regards the potential for survival of the process vessels under combustion pressure loading conditions. If stoichiometric mixtures of hydrogen-air or benzene-air are the target mixtures for analysis, then it will be difficult to rule out vessel failure, given the low design pressure rating of the process vessels. Based upon accepted methods of vessel venting design, it is expected that required vent diameters would be too large to be practicable as a backfit to the existing process vessels. The WSRC project team should verify this conclusion.

\section{Prevention of Combustion Propagation}

The possibility of flame propagation from vessel to vessel through the process vessel vent lines should be designed out. It is suggested flame arrestors be installed at suitable locations in the piping network. These may have to be designed and fabricated (e.g., Matheson Co.) to the diameter useful for the DWPF application and tested for the gases of interest.

Attached to the process vessels are runs of small diameter piping ( 2 in, 3 in, 6 in). It is conceivable that if ignition occured in one of such runs of piping, that run-up to a detonation could occur. The potential for transmission of a detonation from a pipe to a process vessel should be reduced by ensuring that the diameter of the pipe at the connection to a vessel is less than the "critical tube diameter," as discussed in Reference 3.

\section{Eragment and Cell Cover Missile Protection}

Propagation of damage from the initiating event to adjacent vessels and to the facility itself should be designed out. Several possibilities suggest themselves. Among them are:

The possibility of damage to adjacent vessels by fragments resulting from a postulated explosion in an initiating vessel can be defended against by design of fragment shields at the appropriate locations. This is a low-tech fix, assuming that space is available in the cells; steel armored plate would do. This recommendation applies especially to prevent spillage of the OE/OECT vessels which contain benzene.

The possibility of damage to process vessels from falling cell covers is more problematical. Two types of event are responsible for flying cell covers: (i) a benzene-air deflagration or detonation in the Salt Processing Cell and (ii) an explosion in a process vessel, resulting in vessel failure, overpressurization of the cell, displacement of the cell covers and gravity fall on to other vessels in that cell. The most effective way to avoid benzene-air combustion is to 
provide a design fix which would harden the OE/OECT vessels to withstand the design basis earthquake, to prevent spillage of benzene. Benzene inventory in the canyon should be minimized.

Penetration of the DWPF roof by a cell cover missile generated by a deflagration or detonation in the Salt Cell should be mitigated. Calculations based on the model used to compute the cell cover trajectory and impact suggests that increasing the mass of the cell cover by a factor of two would considerably reduce the likelinood of breach of the roof by a cell cover missile, even with conservative assumptions. The cell covers are hollow and could be filled, if the basic structure of the covers will take the additional load. Additionally, the overhead crane must be capable of sustaining the additional weight. This possibility should be considered.

The vessel combustion and failure, cell overpressurization and gravity fall sequence is more difficult to design out. Consideration could be given to anchoring the cell covers and, thereby, avoid the potential for further damage by preventing significant motion.

In general, it is recommended that WSRC take a careful look at all credible modes of damage propagation and consider modifications which would reduce their potential for further accelerating accident sequences.

\section{ASSESSMENT OF COMBUSTION PHENOMENA IN THE ITP WASTE TANKS 48 AND 49}

\subsection{Introduction}

Two WSRC documents (WSRC-RP-93-542 and WSRC-RD-008) related to the question of integrity of the ITP Waste Tanks 48 and 49 under combustion loading have been reviewed. As a result of this review, a series of questions were posed to WSRC. The questions were forwarded to DOE/EH on October 26, 1993. A response was received to these questions during a visit to the site during the week of November 15, 1993. Appendix D of the present review contains copies of the list of questions and the WSRC responses.

The analysis of the ITP waste tanks under consideration postulates that the tanks' vapor spaces fill with stoichiometric mixtures of benzene-air. An ignition source is postulated to initiate combustion in the mixture. Three basic questions have been considered related to this scenario:

(1) What is the mode of combustion of the gas mixture, deflagration, accelerated flame, or detonation?

(2) If the mode of combustion is a deflagration, can the ITP tanks survive the deflagration pressure rise?

(3) If the tanks cannot survive the deflagration pressure rise, what are the consequences in terms of generation of radiological aerosol?

It should be noted that the WSRC ITP project introduced a backup gas purge system which would be introduced following an earthquake. As a result, the project believes that combustible gas mixtures could credibly develop in the ITP tanks and, therefore, that combustion in these tanks is a beyonddesign-basis event. 


\subsection{Mode of Combustion}

The ITP tanks are 85- $\mathrm{ft}$ in diameter and, with a typical vapor space volume of $2600 \mathrm{~m}^{3}$, are an order of magnitude larger than vessels in which combustion experiments have been carried out. With such a large linear distance available for flame acceleration, and with the evaluations based on assumed benzene-air stoichiometric mixtures, the possibility of flame acceleration and deflagration-to-detonation transition must be considered.

The combustion literature suggests that stoichiometric mixtures of sensitive gases such as hydrogen-air may undergo transition to detonation in constrained, one-dimensional geometries such as pipes or rectangular chanriels, as discussed in Reference 4. The flame acceleration distances required to achieve large flame velocities from which transition could occur become small in the presence of structures which act as turbulence-generators to the gas ahead of the flame front.

The benzene tank vapor spaces are large, open volumes with some internal obstacles, in the form of two-inch tubing coils, which would act as turbulence-generators following ignition. The evidence from combustion experiments performed in large, unobstructed geometries is that transition from deflagration to detonation is difficult to achieve, as described in Reference 5. The vapor space geometry presents a large open volume to a flame front which develops from a point source of ignition, with only the internal coils to act as flame accelerators. On the other hand, the linear distance of $85 \mathrm{ft}$ is a very considerable one in terms of the potential to achieve flame acceleration to large flame velocity and possible dynamic loads.

While it is believed that deflagration-to-detonation transition is not likely in such a large, open volume, the stoichiometric benzene-air mixtures are sensitive mixtures, the linear dimension of $85 \mathrm{ft}$ is large, and some internal structure exists. It is this author's judgement that the pressures generated in the ITP tanks would be characteristic of a deflagration rather than a detonation. The possibility of a detonation cannot, however, be completely ruled out with confidence on the basis of known principles or available experimental data.

\subsection{Deflagration Pressure Rise}

The ITP tanks have been backfitted with plugs which are now designed to act as vents, with the intent that they will open relief paths when the vessel pressure reaches $13 \mathrm{psig}$. The ITP deflagration pressure loading calculation methodology in the WSRC reports cited above have been reviewed, as have methods which are industry standards for for sizing vents and for computing pressure rise in vessels with explosion venting [7], [8]. The WSRC document which describes the Deflagration Pressure Analysis Code (DPAC) [9] has also been reviewed.

The WSRC methodology has not been assessed against experimental data from experiments in which gas combustion and venting occur simultaneously. The complications to analysis introduced by the presence of venting are considerable, and data are generally scarce. The adequacy of the methodology, therefore, cannot be assessed and, as a result, the code cannot be used at this time to assess the pressure response of the ITP tanks to a deflagration load in the presence of venting. Because of the large scale of the tanks, it may not be possible to demonstrate that the DPAC code [9] has been adequately verified against a suitable database with all relevant features of the phenomenology adequately represented.

Application of the methodologies of References 7 and 8, which are accepted industry methods for designing vessel explosion vents, lead to predictions that the deflagration pressure rise would greatly exceed the tank failure limit of 21 psig. The computed pressure rises using the two formulations differ, 
however, significantly. Using the method in Reference 8 , the computed deflagration pressure rise for Tank 49 is $3.6 \mathrm{~atm}$, while the method of Reference 7 yields a significanly larger pressure rise. Clearly the two approaches provide different methods of scaling to the conditions of the ITP tanks. It is not clear to me which, if either, of the methods is the more accurate one to use in the present application. Both methods predict pressure rises which greatly exceed the failure limit of the tank and, in addition, the range of pressure rises predicted by the WSRC DPAC code. It is this author's judgement that ITP tank failure resulting from a deflagration cannot be precluded. Prudence would require that the consequences of failure be considered.

\subsection{Waste Tank Failure Mode and Radiological Aerosol Generation}

The major concern regarding the issue of combustion in the vapor space of the waste tanks is that of the potential for radiological release to the environment. The tanks are largely underground. Releases could be to the atmosphere or into the ground, depending on the mode of tank failure.

Tank structural analysis should provide insights into the mode and locations of vessel failure. The vent plugs are likely to lift and create vent paths to the atmosphere. The locations of other openings should be provided by the structural analysis.

The mechanism of aerosol generation must be determined in order to predict the extent of release to the atmosphere, assuming that such vent paths are made available by the explosion. As in the case of the DWPF process vessels, the combusting gas is located above the liquid phase, and the liquid phase is constrained in terms of potential downward motion. The Steindler-Seefeldt methodology is not applicable to the configuration of the deflagration in the tanks, or even a detonation in the tanks. Use of this correlation can lead to erroneous conclusions regarding the potential for large radiological release from a combustion event in the ITP tanks.

\subsection{Recommendations}

This author concludes that the DPAC code cannot be used at this time to predict the deflagration pressure rise in the ITP Waste Tanks, since the code has not been assessed against data from experiments in which combustion and venting were occuring simultaneously. Because the tanks are so much larger than any previous existing experimental test vessels, either with or without venting, it is conceivable that a convincing assessment will not be possible. However, it is recommended that the literature be searched for the largest scale experiments with combustion and venting occuring simultaneously and the data be used to assess the code. The scaling problem and other design-specific problems (such as number of vents and vent locations) will remain, but at least some baselining of the DPAC code will be possible. This exercise may be interesting but may not be entirely convincing.

Perhaps a more fruitful approach would be to focus on the vessel failure mechanism and location resulting from the deflagration pressure rise, and on the mechanism of aerosol production. The release pathways are to the ground and to the atmosphere. This author feels that the Steindler-Seefeldt correlation is not applicable here for the same reasons given above in relation to the DWPF process vessels. It is recommended that an understanding of the aerosol production process be sought in order to attempt to provide a realistic estimate of the radiological release to the atmosphere.

\section{REFERENCES}

1. DWPF Safety Analysis Report, Chapter 9, "Analysis of Operation," DPSTSA-200-10, SUP 20, Rev. 6/93. 
2. Thomas, J.K. and S.J. Hensel, "Pressure Resulting from an ITP Waste Tank Deflagration (U)," WSRC-RP-93-542 (April 1993).

3. Guirao, C.M., et al., "A Summary of Hydrogen-Air Detonation Experiments," Sandia National Laboratories, NUREG/CR-4961 (May 1989).

4. Sherman, M.P., et al., "FLAME Facility," Sandia National Laboratories, NUREG/CR-5275 (April 1989).

5. Brossard, J., et al., "Characterization of the Pressure Field Induced by the Explosions in Air of a Hydrocarbon-Air Mixture, with Slow Deflagration or Fast Deflagration," Proc. of Seminar on the Results of the European Communities' Indirect Action Research Program on Safety of Thermal Water Reactors, Brussels, Belgium (October 1984).

6. Steindler, M.J. and W.B. Seefeldt, "A Method for Estimating the Challenge to an Air Cleaning System Resulting from an Accidental Explosive Event," 16th DOE Nuclear Air Cleaning Conference, CONF-801038, Vol. 2 (February 1981).

7. National Fire Protection Association, "Guide for Venting of Deflagrations," NFPA 68, Committee on Explosion Protection Systems, A.R. Albrecht, Chair (1988).

8. Baker, W.E. et al., "Explosion Hazards and Evaluation, " Chapter 3, Elsevier Scientific Publishing Co., New York (1983).

9. Hensel, S. J., "Description and Benchmarking of the Deflagration Pressure Analysis Code (DPAC)," WSRC-RD-93-008 (April 1993). 
TABLE 1

IMPORTANT DWPF SCENARIOS AND ASSUMPTIONS

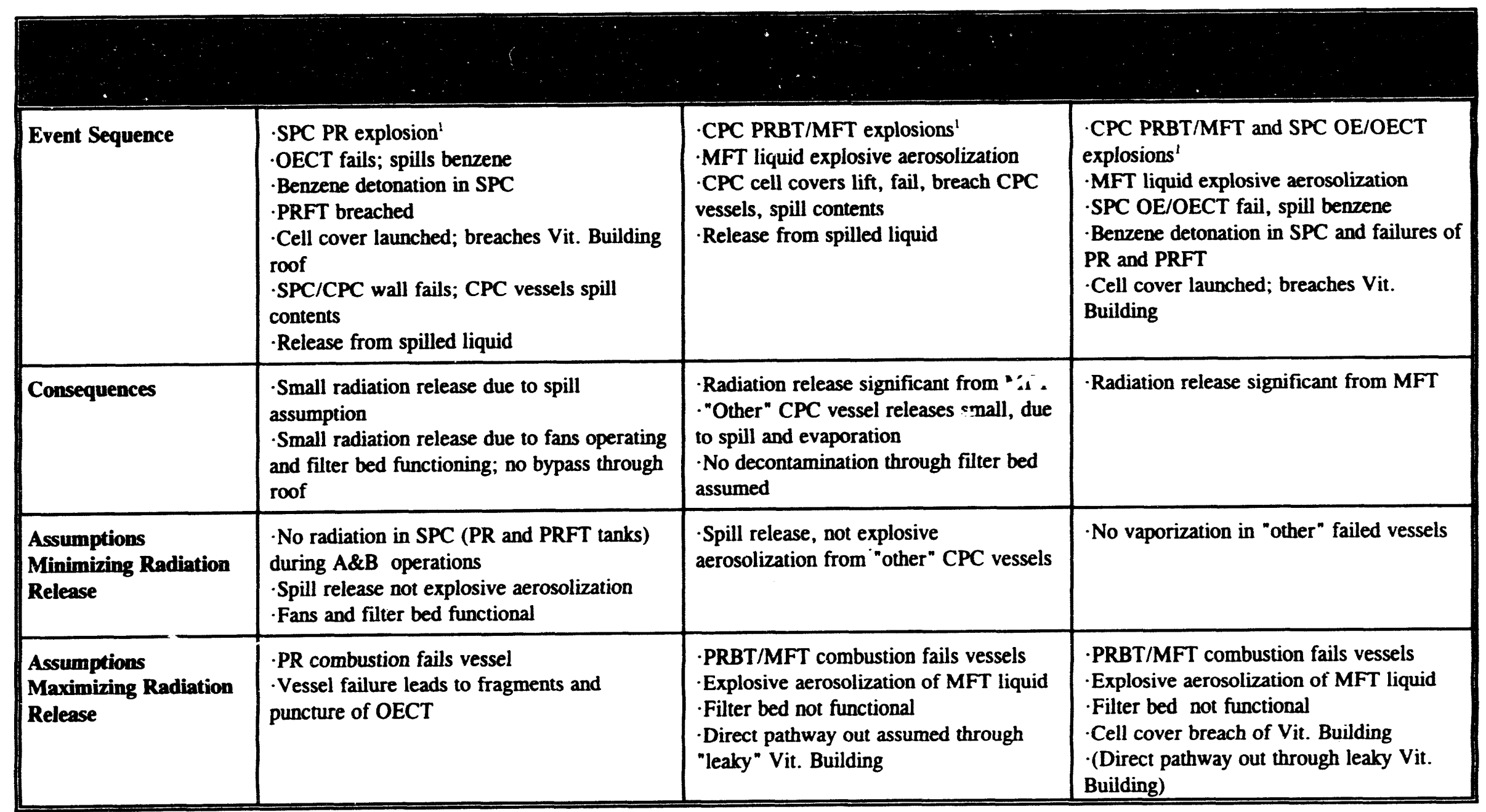

1"Explosion" is used in DWPF SAR to mean a gas phase combustion event in a process vessel, accompanied by energetic vessel failure. 


\title{
APPENDIX A
}

\section{PRELIMINARY REVIEW OF THE DWPF SAR FROM THE POINT OF VIEW OF RISK OF RADIONUCLIDE RELEASE FROM THE PLANT}

\author{
T. Ginsberg \\ Brookhaven National Laboratory \\ Department of Advanced Technology \\ Safety and Risk Evaluation Division \\ Upton, NY 11973
}

\section{INTRODUCTION}

The DWPF is a complex chemical plant whose risk profile is significantly impacted by the radionuclide inventory which is stored in the process material. The risk to the public and to plant operating staff is due to both chemical and radionuclide releases. The potential exists for radionuclide releases resulting from occurrences, such as spills, which may occur relatively frequently during the life of the plant but have small radionuclide release consequences, to occurrences, such as explosions, resulting from the release of chemical energy or stored thermal energy which could, under pessimistic assumptions, lead to unacceptably high radionuclide releases. This review will focus on the risk profile of the DWPF from the point of view of the potential for "large" radionuclide release from the plant to the SR site and to beyond the site boundary.

This review is based upon my reading of Chapter 9 of the SAR on a trip to the DWPF which took place on September $21-23,1993$, during which time I toured the facility along with other members of the DOE/NS Review Team and on discussions with WSRC staff engineers who are responsible for both phenomenological analysis and event tree analysis. The DWPF SAR is in a state of flux. Changes are being considered to both process and potential safety features of the plant. As a result, this review is preliminary. The objective of this review is to provide an overall perspective to the material presented in Chapter 9, to provide an assessment of the methods being used to draw safety conclusions concerning the plant, to highiight improvements in plant features which could significantly improve the safety of the plant from the point of view of either reducing the likelihood of entering into release scenarios, or reducing the quantity of radionuclides which would be released if such an event occurred, and to provide focus to the most important issues which must be addressed in the review of the DWPF SAR.

\section{OVERVIEW OF THE DWPF SAR FROM THE VIEWPOINT OF RADIONUCLIDE RELEASE}

In Chapter 9 of the DWPF SAR, the WSRC project has presented the results of a PRA which is intended to provide a risk profile of the plant. I believe that this effort is a good first pass at developing an understanding of the safety of the plant. This effort has highlighted a number of important features which, in a sense, simplifies analysis of the plant from the point of view of "large" radionuclide releases. For the purpose of this analysis, I will take "large" release as one which leads to a dose of "rems" to an individual on the site boundary. From this point of view, the SAR demonstrates that a release leading to this magnitude of dose would have to result from an "explosive" dispersal of radioactive aerosol, as opposed to a release from a spill 
or a leak. This makes phenomenological sense, and is an important point which provides focus to the review of the SAR from the point of view of radionuclide release: The risk related to radiological release is associated with accident progressions which lead to explosive energy release.

WSRC has identified accident scenarios which lead to explosions in their process vessels, in their process cells and in the cell ventilation system. Gas phase chemical explosions, melt-water steam explosions and solid phase explosions have been identified as resulting from some accident progressions which are initiated by internal events and by earthquakes. WSRC summarizes their risk and consequences profile for the DWPF in their Tables 9.0-3 through 9.0-8. I have used this information together with the detailed discussions provided in the text to provide a broad overview of the results of the current WSRC analysis. This is presented in summary quantitative form in the enclosed Table A-1. I have presented the information in terms of "lines of defense" to release of radiological inventory for internal and external (earthquake) events. The first line of defense is the reliability of plant equipment and its operators to prevent attainment of explosive conditions in any of the process vessels. The second line of defense is the capability of the process vessels to contain the explosive release of energy and thereby contain the inventory of radionuclides within the process vessel(s). Finally, the third line of defense is the capability of the DWPF building and the sand bed filter system to mitigate the consequences of explosive failure of the process vessels by removing the bulk of radionuclides from the ventilation gas by natural plateout processes or by decontamination within the filter bed.

Based upon the current WSRC analysis, the combination of postulated internal systems failures and human errors would lead to conditions of buildup of combustible gases to explosive concentrations within process vessels and availability of ignition sources with a frequency of less than $10^{-3}$ events per year. This may be a conservative number, but this is what is presented. In their current analysis, WSRC suggests that upon attainment of conditions for combustion the process vessel under consideration would fail explosively. Based upon their current analysis, no credit is given for vessel integrity. The inventory of the vessel is explosively released and aerosolized, with the extent of suspended aerosol computed using a correlation from the literature. Additionally, the failure of a first vessel generally is modeled as leading to subsequent (nonexplosive) vessel failures. This will be discussed in greater detail in Section 3.2. For internal events, the radiological releases are mitigated by the presence of the sand bed filter. With the filter bed performing its function, the radiological releases from the plant are quite small. The likelihood of a release leading to a dose of "rems" or greater for an internal event with active filter bed is about $10^{-6}$.

A $0.2 \mathrm{~g}$ earthquake is presented with a frequency of $2 \times 10^{-4}$ per year. The earthquake leads to support systems failures, followed by a buildup to explosive concentrations in selected process vessels. As in the case of internal events, the failure of a first vessel generally is modeled as leading to subsequent (nonexplosive) vessel failures. Availability of ignition sources then leads to explosive vessel failure, i.e., no credit is given by WSRC to the capability of the process vessels to contain the vessel chemical and radiological inventory. As in the case of internal events, the failure of a first vessel generally is modeled as leading to subsequent (nonexplosive) failures of adjacent vessels within the same process cell. No credit, apparently, is given for decontamination of the resulting suspended aerosol by the sand filter bed, which is assumed to be unavailable as a result of damage by the earthquake. Releases leading to doses of "rems" or greater are predicted with frequency of the order $5 \times 10^{-5}$. The relatively large doses are due to loss of the function of the sand filter beds. The reasons for the reduction of frequency from $2 \times 10^{-4}$ to $5 \times 10^{-5}$ are not clear.

This overview picture of the current DWPF SAR provides us with insights on the strengths and weaknesses of the DWPF plant (on paper, anyway) from the point of view of risk of large radiological release. It 
provides us with the ability to focus on the important issues, to ask relevant questions and to suggest alternative approaches to risk reduction if deemed appropriate.

For internal events, we must verify, by analysis of the system fault trees and supporting databases, the reported systems hardware failure frequencies and human error frequencies, in order to determine whether the likelihood of attainment of explosive conditions are as unlikely as claimed by WSRC. Particular attention must be focused on gas purge system reliability. Conversations with WSRC staff suggest that they are not happy with their current conclusion with respect to vessel integrity under combustion conditions. They are redoing their analysis and are considering hardware modifications. We have not heard the final story here. My additional comments on explosions and vessel integrity are presented in Section 3.2. The sand bed filter is clearly critical to the risks associated with internal events, and we must verify that its availability upon demand for decontamination is as reported. We must also verify their source term and dose calculations.

The current DWPF analysis of external events leads to the conclusion that the $0.2 \mathrm{~g}$ earthquake leads to a nearly unmitigated release of radiological inventory and a dose of "rems" or greater at the site boundary. Multiple vessel failures lead to direct release to the environment, since the sand filter bed are assumed to be bypassed as a result of earthquake damage to the ventilation system fans. The filtration system is not earthquake qualified.

As for the case of internal events, WSRC is working on the question of vessel integrity.

We must, of course, verify the WSRC earthquake frequency assumptions. Additionally, we also must verify their source term dose calculations.

This overview suggests a number of major issues which should be addressed by the DOE/NS review team. My suggestions are discussed in Section 3. I have formulated a number of questions which I would recommend posing to WSRC. These are presented in Section 4. The overview has also provided some ideas for potential safety improvements to plant features, which I discuss in Section 5.

\section{SUGGESTED ISSUES TO BE ADDRESSED BY DOE/NS REVIEW TEAM}

\subsection{Explosion and Explosion Propagation Issues}

The WSRC analysis of combustible gas accumulation and combustion is evolving, and we will have to keep careful track of developments. One critical issue, however, has become clear as a result of interactions with WSRC staff. The WSRC accident progression for explosive sequences begins with accumulation of combustibles following by an explosive energy release in one of the process vessels. The liquid inventory of this vessel is aerosolized as a result of the explosion. This "primary" explosion, however, leads to a "domino" sequence of secondary vessel failures, resulting from one of two causes: (i) the cell containing the vessel pressurizes as a result of the vessel failure, the cell covers are lifted by the resulting pressure and then fall and damage the adjacent vessels in that cell, or (ii) fragments resulting from explosion of the first vessel puncture adjacent, "secondary", vessels, resulting in their failure. The critical point, however, is that the secondary vessels are assumed to spill their contents onto the cell floor. This mode of release of material from the adjacent vessels is a benign release and does not lead to significant additional aerosolized inventory of material. However, if the first vessel is assumed to contain explosive combustibles, then it may be assumed, unless otherwise demonstrated, that the secondary vessels may also contain explosive combustibles 
in the gas space. If this is the case, then it is conceivable that the adjacent vessels would also undergo ignition to explosions upon impact and failure by falling objects and high-velocity flying fragments. To my mind, WSRC must demonstrate why secondary explosions are not possible, rather than benign failure and spillage of vessel contents. If, indeed, secondary explosions are a possibility, then the source term would be increased by explosive aerosolization of the contents of the secondary vessels.

If it is assumed that a single vessel undergoes explosive combustion, then the question of propagation to adjacent vessels must be considered, as discussed above. In addition to the cell covers and vessel fragments as sources of damage of adjacent vessels, there exist common gas space piping between vessels. While I do not have a clear picture of the connecting piping network, discussions with WSRC staff indicate the existence of such a network. As a result, a combustion event which is initiated in one vessel may be able to propagate to adjacent vessels if combustible mixture exist in those vessels. This additional mode of propagation was not considered in the DWPF and must be considered in future analyses.

In the DWPF SAR, it is not always clear what mode of combustion is being discussed in the process vessels and in the process cells. We need to get a better definition, for each postulated event, the mode of combustion which is being considered. The possibility of propagation from vessel to vessel will depend on whether we are talking about a detonation or a deflagration.

It is clear that the possibility of vessel failure propagation from an initiating vessel explosion to secondary vessel failures is a weak link in the DWPF safety profile. This possibility must be considered by WSRC. The additional pussibility that the secondary failures could be accompanied by explosions was not considered by WSRC, and we must ensure that they address the issue. Of course, the best thing they could do is to design out the potential for explosions and explosion propagation.

Implicit in the DWPF SAR and in the discussions we had with WSRC personnel, that process chemistry is slow and non-energetic and that runaway reactions are not likely under nominal operating conditions or small deviations from nominal. This issue should be looked at by competent chemists and put to bed if possible.

The SAR concludes that a steam explosion in the glass melter which would threaten the integrity of the melter is vanishingly small. The reasons given are that as long as the melter is near design temperature, the glass matrix viscosity is so high that steam explosions are highly unlikely, even if water could be introduced into the melt. The only credible source of steam explosions according to the SAR would be due to an overlying layer of salt on top of the glass. The SAR assigns the existence of such a salt layer a likelihood of $10^{-7}$. This has to be checked out.

\subsection{Vessel Purge System Reliability}

Continual successful operation of the vessel purge system is probably the best way to ensure that combustible mixtures do not develop in any of the process vessels or cells. We should look carefully at system reliability during internal events to ensure that the hardware is consistent with the failure probability presented in the SAR. 


\subsection{Source Term and Dose Calculation}

Based on the WSRC SAR, the only way to get a "large" radionuclide release from internal events is to combust explosively and to fail to mitigate by flow through the sand bed filter. This combined sequence of events has a computed frequency of the order of $10^{-6}$. We should verify that explosions in the cells will not affect the performance of the filter bed and that, in general, the filter bed system reliability is as claimed in the SAR.

The WSRC release and dose calculations should be verified by independent calculation.

\subsection{External Event Frequency}

The $0.2 \mathrm{~g}$ earthquake frequency is given as $2 \times 10^{-4}$. This number should be confirmed. Additionally, the rationale for the reduction of external event frequency from $2 \times 10^{-4}$ to $5 \times 10^{-5}$ should be clarified.

\section{QUESTIONS TO BE POSED TO WSRC}

A number of questions have arisen during my review of the DWPF SAR. As a result, I have a number of questions and requests for information that I would recommend be forwarded to WSRC:

(1) What are the modes of comihustion postulated for each of the process vessels: deflagration or detonation?

(2) What are the possible mechanisms of detonation initiation in the process vessels?

(3) Provide a description of the analysis which indicates that cell covers are lifted and will crush underlying vessels.

(4) Provide a description of the analysis which indicates that the adjacent vessels would be punctured by fragments from first vessel failure.

(5) Provide rationale for the assumption that secondary failures are not accompanied by explosions. Why spill and not explosion?

(6) Provide the rationale for the number of vessels chosen, and particular vessels chosen, to initially explode in the case of earthquake. Why only two vessels, and why those specific ones.

(7) What is effect of a process vessel explosion on operations of sand bed filter?

(8) Aside from deposition in the sand bed filter, does analysis assume other aerosol settling and plateout mechanisms?

(9) Describe the vapor cloud explosion in the SPC. Is this a deflagration or detonation? Show the analysis which shows that a cell cover would be propelled to breach the Vitrification Building. 
(10) Describe all mechanisms whereby deflagrations or detonations can be propagated from one vessel to another vessel.

(11) Provide the rationale for the external event frequency of $5 \times 10^{-3}$ per year, given the earthquake frequency of $2 \times 10^{-4}$ per year.

\section{POTENTIAL SAFETY IMPROVEMENTS}

A number of potential improvements suggest themselves on the basis of this preliminary review of the DWPF SAR:

(1) The frequency of development of explosive mixtures in the process vessels can, I believe, be reduced significantly through the incorporation of an earthquake-certified gas purge system, which would kick in automatically upon failure of "normal" purge. This would help both internal and external event frequencies.

(2) According to this current SAR, the process vessels provide no mitigation function, given a combustible mixture within the vessels.

I believe that steps should be taken to eliminate the potential for sequential failure of the process vessels. The "domino" possibility leads to many uncertainties. The cell covers can either be fixed in place or, following $\mathbf{R}$. Fullwood, they can be made of a lighter material which would not crush the underlying vessels upon impact. Additionally, fragments from failure of one vessel should be shielded from adjacent vessels.

Obviously, the ideal solution, is to ensure that no vessel failures occur.

(3) Earthquake-hardening the sand bed filter would, of course, provide great mitigating potential for the external event. It should be considered. This would reduce potential exposures to much less than "rems." 
TABLE A-1

OVERVIEW OF DWPF SYSTEMS PERFORMANCE AS PRESENTED IN SAR

\begin{tabular}{|c|c|c|}
\hline LEVIL OF DANDNSE & $\begin{array}{l}\text { INTWRNAI } \\
\text { (Failure Frequency or Conditional } \\
\text { Probability of Fallure) } \\
\end{array}$ & $\begin{array}{c}\text { EXTMRNAL } \\
\text { (Failure Frequeney or Conditional } \\
\text { Probability of Bailure) }\end{array}$ \\
\hline $\begin{array}{ll}\text { 1st - } & \begin{array}{l}\text { Prevent explosive concentration and } \\
\text { ignition }\end{array} \\
\end{array}$ & $<10^{-3} / \mathrm{yr}$ & $\begin{array}{c}-5 \times 10^{-5} / \mathrm{yr} \\
(0.2 \mathrm{~g} \text { earthquake) } \\
\end{array}$ \\
\hline 2nd - Process vessel integrity & 1 & 1 \\
\hline 3rd - Decontamination by sand bed filter & $10^{-3}$ & 1 \\
\hline Release leading to "rems" release frequency & $<10^{-6} / \mathrm{yr}$ & $-5 \times 10^{-5} / \mathrm{yr}$ \\
\hline
\end{tabular}




\title{
APPENDIX B
}

\section{QUESTIONS FOR WRSC ON DWPF SAR}

\author{
T. Ginsberg \\ Brookhaven National Laboratory \\ Department of Advanced Technology \\ Safety and Risk Evaluation Division \\ Upton, NY 11973
}

\begin{tabular}{|c|c|c|c|}
\hline Sothon. & A & & Questions \\
\hline $\begin{array}{l}9.5 .2 .1 \\
9.6 .4\end{array}$ & $\begin{array}{l}9.5-2 \\
9.6-3\end{array}$ & $\begin{array}{l}\text { TG } \\
\text { TG }\end{array}$ & $\begin{array}{l}\text { What are the modes of combustion postulated for each of the process vessels: } \\
\text { deflagration or detonation? }\end{array}$ \\
\hline $\begin{array}{c}9.5 .2 .1 \\
9.6 .4\end{array}$ & $\begin{array}{l}9.5-2 \\
9.6-3\end{array}$ & $\begin{array}{l}\text { TG } \\
\text { TG }\end{array}$ & $\begin{array}{l}\text { What are the possible mechanisms of detonation initiation in the process } \\
\text { vessels? }\end{array}$ \\
\hline $\begin{array}{c}9.5 .2 .1 \\
9.6 .4\end{array}$ & $\begin{array}{l}9.5-2 \\
9.6-3\end{array}$ & $\begin{array}{l}\text { TG } \\
\text { TG } \\
\end{array}$ & $\begin{array}{l}\text { Provide a description of the analysis which indicates that cell covers are lifted } \\
\text { and will crush underlying vessels. }\end{array}$ \\
\hline $\begin{array}{c}9.5 .2 .1 \\
9.6 .4\end{array}$ & $\begin{array}{l}9.5-2 \\
9.6-3\end{array}$ & $\begin{array}{l}\text { TG } \\
\text { TG }\end{array}$ & $\begin{array}{l}\text { Provide a description of the analysis which indicates that the adjacent vessels } \\
\text { would be punctured by fragments from first vessel failure. }\end{array}$ \\
\hline $\begin{array}{c}9.5 .2 .1 \\
9.6 .4 \\
\end{array}$ & $\begin{array}{l}9.5-2 \\
9.6-3 \\
\end{array}$ & $\begin{array}{l}\text { TG } \\
\text { TG } \\
\end{array}$ & $\begin{array}{l}\text { Provide rationale for the assumption that secondary failures are not } \\
\text { accompanied by explosions. Why spill and not explosion? }\end{array}$ \\
\hline $\begin{array}{c}9.5 .2 .1 \\
9.6 .4\end{array}$ & $\begin{array}{l}9.5-2 \\
9.6-3\end{array}$ & $\begin{array}{l}\text { TG } \\
\text { TG }\end{array}$ & $\begin{array}{l}\text { What would be the impact on the radiological source term if the secondary } \\
\text { vessel failures were accompanied by explosive aerosolization of the vessel } \\
\text { contents? }\end{array}$ \\
\hline 9.6.4 & $9.6-3$ & TG & $\begin{array}{l}\text { Provide rationale for the number of vessels chosen, and particular vessels } \\
\text { chosen, to initially explode in the case of earthquake. Why only two vessels } \\
\text { and why the specific ones chosen? }\end{array}$ \\
\hline 9.5.2.1 & $9.5-2$ & TG & What is the effect of a process vessel explosion on operation of sand bed filter? \\
\hline 9.5.2.1 & $9.5-2$ & TG & $\begin{array}{l}\text { Aside from deposition in the sand bed filter, does analysis assume other aerosol } \\
\text { settling and plateout mechanisms? }\end{array}$ \\
\hline $\begin{array}{l}9.6 .4 \\
9.5 .2 .2\end{array}$ & $\begin{array}{l}9.6-4 \\
9.5-8\end{array}$ & $\begin{array}{l}\text { TG } \\
\text { TG }\end{array}$ & $\begin{array}{l}\text { Describe the vapor cloud explosion in the SPC. Is this a deflagration or } \\
\text { detonation? Show the analysis which shows that a cell cover would be } \\
\text { propelled to breach the Vitrification Building. }\end{array}$ \\
\hline $\begin{array}{c}9.5 .2 .1 \\
9.6 .4\end{array}$ & $\begin{array}{l}9.5-2 \\
9.6-3\end{array}$ & $\begin{array}{l}\text { TG } \\
\text { TG }\end{array}$ & $\begin{array}{l}\text { Describe all mechanisms whereby deflagrations or detonations can be } \\
\text { propagated from one vessel to another vessel. }\end{array}$ \\
\hline 9.6.4 & $9.6-3$ & TG & $\begin{array}{l}\text { Provide the rationale for the external event frequency of } 5 \times 10^{-5} \text { per year, given } \\
\text { the earthquake frequency of } 2 \times 10^{-4} \text { per year. }\end{array}$ \\
\hline
\end{tabular}




\title{
APPENDIX C
}

\section{CELL COVER LIFTING DUE TO AN INTERNAL EXPLOSION}

\author{
G. Ciccarelli and T. Ginsberg \\ Brookhaven National Laboratory \\ Department of Advanced Technology \\ Upton, NY 11973-5000
}

\section{INTRODUCTION}

In the event of a release of benzene to the Salt Processing Cell, WSRC has postulated that if a detonation of a stoichiometric mixture of benzene-air occurs, then the detonation would lead to cell pressures large enough to accelerate the cell covers to velocities large enough to impact the DWPF roof and punch a hole through the concrete. The WSRC analysis was carried to the point of calculation of the cell cover velocity at impact with the roof, and did not actually consider the concrete penetration mechanism using available data and correlations. The analysis reported here was carried out to determine the likelihood of penetration of the concrete roof of the DWPF by a cell cover missile.

In this analysis, we consider the launching of the Salt Process Cell (SPC) covers as a result of combustion processes which are characterized by (i) the propagation of a chemical detonation wave through a stoichiometric benzene-air mixture contained within the cell, and (ii) the constant volume deflagration of these mixtures. The cell is taken to be $6.7 \mathrm{~m}(22 \mathrm{ft})$ wide, $15.8 \mathrm{~m}(52 \mathrm{ft})$ long, and

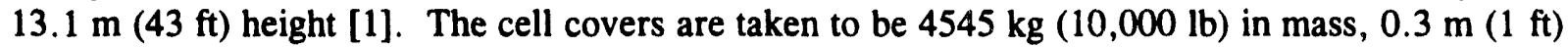
thick and $2.7 \mathrm{~m}(9 \mathrm{ft})$ wide spanning the width of the cell [1]. The distance from the top of the cell cover to the concrete ceiling is taken to be $12.2 \mathrm{~m} \mathrm{(40} \mathrm{ft)} \mathrm{[1].} \mathrm{The} \mathrm{reinforced} \mathrm{concrete} \mathrm{roof} \mathrm{is} \mathrm{taken} \mathrm{as}$ $1.22 \mathrm{~m}(4 \mathrm{ft})$ thick [2].

In order for a cell cover to pose a threat to the concrete roof of the DWPF, it must be launched with sufficient velocity to enable it to reach the roof with sufficient kinetic energy so as to puncture the concrete following impact. A simplified model will be used which assumes uniform loading of a single cell cover, no interactions with adjacent cell covers during its trajectory, no spinning of the cover after it is launched. These assumptions enable us to compute the kinetic energy at impact of the cell cover with the roof, given the combustion pressure loading history. At impact, an available ballistic impact data correlation [3] is used to assess the potential for penetration of the reinforced concrete. No data have been found for missiles with the geometry of the hollow cell covers. Assumptions are made about the shape of the cover at impact in order to permit use of the correlations. Energy absorption resulting from deformation of the cell covers at impact is not treated. It is believed that these assumptions are conservative. Relaxing these assumptions, however, appears to be difficult, as a result of the lack of appropriate data and models. 


\section{CELL COVER COMBUSTION LOADING MODELS}

The analysis performed here is based on the equations of motion for a single cell cover. A cell cover would be influenced by forces during two time periods: (i) the initial period during which time the cover begins to lift, but no venting of combustion products around the cover has yet occured, and (ii) venting of gases around the cover causes a flow field which influences the forces acting on the cover.

\section{Detonation Combustion Model}

A detonation in the SPC would lead to a pressure-time history on the cell covers which begins with a nearly instantaneous rise to the Chapman-Jouget (C-J) [4] detonation pressure, followed by a decay of the pressure with some time constant (see below) to the constant volume deflagration pressure. The cell pressure is assumed to be unaffected by the initial motion of the cell cover. This is due to the large volume (or internal energy) of the cell gas. Only at the later stages when the cell gas is vented is the pressure relieved. For example, the cell volume increase before venting is $5.4 \mathrm{~m}^{3}$ (i.e., $2.7 \mathrm{~m} \mathrm{x} 6.7 \mathrm{~m}$ x $0.3 \mathrm{~m}$ ) which is negligible compared to the cell volume of $1386.8 \mathrm{~m}^{3}$ (i.e., $6.7 \mathrm{~m} \mathrm{x} 15.8 \mathrm{~m} \mathrm{x}$ $13.1 \mathrm{~m})$.

It is assumed that a detonation is initiated in the cell due to the presence of turbulence-inducing equipment within the cell volume. The impulse which a cover would be subjected to is dependent on the shape of the detonation (e.g., spherical, cylindrical or planar) and on the distance from the point of initiation to the cover. Figure 1 shows the shape of the detonation wave for two idealistic scenarios. In Figure 1a, the detonation is initiated at midspan of the cell so that a spherical detonation exists throughout the cell. In Figure 1b, the detonation is initiated at one end of the cell and it quickly assumes a planar shape.

The scenario which would result in the largest pressure loading on any one of the covers is that one depicted in Figure 1b. In this scenario the cell cover at the opposite end would be subjected to the highest pressure and impulse. The peak pressure would be that for a reflected Chapman Jouget, $P_{R}$, detonation wave (e.g., typically 2.5 times the $\mathrm{CJ}$ detonation pressure) as it reflects off the endwall. The impulse is the largest since this is the furthest cover from the point of initiation. The pressure distribution behind a planar detonation wave is shown in Figure 2. As the wave propagates down the length of the cell all the covers would be set into motion. Since the wave speed is very high (e.g., $2000 \mathrm{~m} / \mathrm{s}$ ), and the covers are massive, venting of products would not effect the propagation.

We will assume that there are no pressure gradients on the cover surface, that is the cover is uniformly loaded. Neglecting gravity during the acceleration phase, the equation of motion for the cover is given by

$$
\int U d U=\int \frac{P A}{M} d x
$$

where $\mathrm{x}$ is the distance travelled by the cover, $\mathrm{P}$ is the net vertical pressure on the cover and $\mathrm{M}, \mathrm{U}$ and $A$ is the mass, velocity and cross-sectional area of the cover, respectively.

At time zero, the cover is subjected instantly to the reflected detonation pressure equal to 2.5 times the CJ pressure for the mixture in question. This pressure then decays roughly exponentially to about the constant volume deflagration pressure. For this analysis, we will assume that the pressure decays linearly with a characteristic relief time equal to the time for an expansion wave to propagate through 
that portion of the products in motion (i.e., slug of gas half the length of the distance travelled by the detonation wave). The acoustic unloading time, $\tau$, is

$$
\tau=\frac{L}{2 C}
$$

where $\mathrm{L}$ is the length of the cell and $\mathrm{c}$ is the sound speed in the combustion products. Therefore, the pressure load time history on the last cover, for times less than the acoustic unloading time, is

$$
\boldsymbol{P}=\boldsymbol{P}_{\boldsymbol{R}}-\left(\boldsymbol{P}_{\boldsymbol{R}}-\boldsymbol{P}_{c V}\right)\left(\frac{t}{\tau}\right)-\boldsymbol{P}_{\text {. }}
$$

where $P_{e}$ is the ambient pressure and $t$ is the time.

After the acoustic time, it is assumed that the cell reaches a uniform pressure equal to the constant volume pressure, $\mathrm{P}_{\mathrm{cv}}$. The cell remains at this pressure until the cover has travelled $0.3 \mathrm{~m}$ at which point the cell contents begin to vent. The vented gas flows radially through the gap between the cover in motion and the stationary covers, as shown in Figure 3. This flow is choked at the minimum cross sectional flow area which initially is located at the gap. As the cover lifts further up the gap area eventually becomes larger than the cell opening (e.g., gap height of $1.37 \mathrm{~m}$ ) and as a result the choking plane moves to the cell opening. At this point, an under expanded jet is setup with the cover riding on top. This problem was analyzed by Baum [5] for a small missile ejected from a vessel containing high pressure. The analysis of this portion of the cover acceleration in the present study is very difficult since details of the jet structure (e.g., axial pressure, density, and velocity profiles) are influenced by the large size of the missile. Therefore, we will only consider the cover acceleration up to the point where the choking plane switches to the cell opening, $x=1.67 \mathrm{~m}$.

While the flow is choked at the gap, the net vertical pressure on the cover can be calculated as follows

$$
P=P_{w}+P_{w}\left(V_{w}-U\right)\left|V_{w}-U\right|-P \text {. }
$$

where $P_{w}, \rho_{w}, V_{w}$ are the pressure, density and flow velocity evaluated at the cell opening, $U$ is the cover velocity, $\mathbf{P}_{e}$ is the ambient pressure, and $w$ represents conditions at the cell opening. In order to calculate the static pressure, density and velocity at the cell opening the Mach Number is required. Assuming perfect gas and one dimensional isentropic flow the Mach Number, $\mathbf{M}_{w}$, at the cell opening can be calculated iteratively from the following expression

$$
\frac{A_{w}}{A^{*}}=\frac{1}{M_{w}}\left[\frac{1+\frac{Y-1}{2} M_{w}^{2}}{\frac{Y+1}{2}}\right]^{\frac{Y+1}{2\left(Y^{-1}\right)}}
$$

where $A_{w}$ is the cell opening area, $A^{*}$ is the gap area (e.g., choking plane area), and $\gamma$ is the ratio of specific heats. The sound speed $c_{w}$, density $p_{w}$, and pressure $P_{w}$ can then be computed as follows

$$
\frac{c_{0}}{c_{w}}=\left(1+\left(\frac{Y-1}{2}\right) M_{w}^{2}\right)^{\frac{1}{2}}
$$




$$
\begin{aligned}
& \frac{\rho_{0}}{\rho_{N}}=\left(\frac{c_{0}}{c_{N}}\right)^{\frac{2}{v-1}} \\
& \frac{P_{0}}{P_{N}}=\left(\frac{\rho_{0}}{\rho_{N}}\right)^{v}
\end{aligned}
$$

where the subscript o denotes cell conditions.

The flow velocity, $\mathrm{V}_{\mathrm{w}}$, and mass flow rate, $\mathrm{m}$, at the cell opening can be calculated as follows

$$
\begin{aligned}
& V_{w}=M_{w} C_{w} \\
& m=\rho_{N} A_{w} V_{w}
\end{aligned}
$$

Taking a control volume which includes the gas inside the cell, we can perform an open system analysis to determine the pressure drop in the cell. Assuming no heat losses to the cell walls, conservation of energy states that the change in internal energy equals the amount of enthalpy lost through the venting

$$
(m \Delta t) h=M_{1} u_{1}-M u
$$

where $M_{i} u_{i}$ and $h$ are the gas mass, internal energy, and enthalpy, respectively. Subscript $i$ denotes initial gas values. From conservation of mass, we get

$$
M_{1}-M=m \Delta t
$$

Substituting (12) into (11) and assuming ideal gas, we get the following relationship for the change in cell pressure, $P$, over time

$$
\frac{P}{P_{i}}=\frac{M_{1}-m \Delta t}{M_{1}+(Y-1) m \Delta t}
$$

The cover velocity and cell pressure as a function of distance travelled were computed numerically by integrating Equations (1) and (13) for initial cell mixtures of stoichiometric benzene-air. The following table gives the mixture properties used in solving the equations. 


\begin{tabular}{||c|c|c|c|c||}
\hline & $\begin{array}{c}\text { CJ Pressure } \\
(\mathrm{atm})\end{array}$ & $\begin{array}{c}\text { Adiabatic Constant } \\
\text { Volume Pressure, } \mathrm{P}_{\mathrm{cv}} \\
(\mathrm{atm})\end{array}$ & $\begin{array}{c}\text { Products Density } \\
\left(\mathrm{kg} / \mathrm{m}^{3}\right)\end{array}$ & $\begin{array}{c}\text { Products Sound } \\
\text { Speed } \\
(\mathrm{m} / \mathrm{s})\end{array}$ \\
\hline Benzene-air & $18.8^{\circ}$ & $9.4^{\circ}$ & $1.26^{*}$ & $1000^{* *}$ \\
\hline
\end{tabular}

- The constant volume pressure for benzene-air was taken from [6] and $P_{\mathrm{CJ}}$ was taken to be two times $P_{\mathrm{Cv}}$ which is typical for most hydrocarbon mixtures [4].

-. Density and sound speed were calculated using perfect gas law and a combustion gas product temperature of $3000 \mathrm{~K} \mathrm{[6]}$ and a value of 1.2 for the ratio of specific heats.

The results of the calculation for stoichiometric benzene-air are given in Figure 4. The initial pressure exposed to the cover is about $45 \mathrm{~atm}$ which then decays linearly over a time equal to the acoustic unloading time (i.e., $7 \mathrm{~ms}$ ). However, as can be seen in both Figures 4 and 5 the cover reaches $0.3 \mathrm{~m}$, at which point venting commences, before the pressure relief to the constant volume pressure is complete. In the calculation the cell pressure is automatically set to the constant volume pressure when the cover has travelled $0.3 \mathrm{~m}$ and thus we get a discontinuity in the pressure. As can be seen the cover accelerates very rapidly during this time reaching a maximum of about $70 \mathrm{~m} / \mathrm{s}$ in 0.3 meters travelled. Once the venting phase starts the acceleration dramatically drops but remains positive. The final velocity achieved by the cover by the time it reaches a distance $1.67 \mathrm{~m}$ is $128 \mathrm{~m} / \mathrm{s}$ for benzene-air.

\section{Deflagration Combustion Model}

A third calculation was performed where it was assumed that the initial cell pressure was equal to the constant volume pressure and remained so until the cover travelled 0.3 meters. The results for benzene-air are given in Figure 5. The final cover velocity under constant volume conditions is 106 $\mathrm{m} / \mathrm{s}$ compared to $128 \mathrm{~m} / \mathrm{s}$ for the case where a reflected detonation type load is applied.

\section{CELL COVER IMPACT WITH CONCRETE ROOF AND POTENTIAL FOR PENETRATION}

As discussed earlier, it is very difficult to continue the analysis to the point where the cover hits the ceiling located at a discance of $12.2 \mathrm{~m}$. Nevertheless, assuming that there is no further contribution of the venting gas to the cover after 1.67 meters we can calculate the deceleration of the cover due to gravity. The cover velocity as a function of distance in a gravitational field is given by

$$
v_{2}^{2}=v_{1}^{2}-2 g \Delta x
$$

The final impact velocity, under initial detonation loading for the case of stoichiometric benzene-air is $127 \mathrm{~m} / \mathrm{s}$. Clearly, deceleration due to gravity over a distance of $10.83 \mathrm{~m}$ is negligible.

At this point, it would be of interest to determine whether or not the cover would perforate the concrete slab ceiling upon impact. The following Modified NDRC Formula [3], which is applicable to spherical nosed missiles impacting concrete slabs, was used as a criterion for concrete perforation 


$$
\begin{aligned}
\left(\frac{x}{4 d}\right)^{2} & =2.55 \times 10^{-9} K d^{0.2} D v^{1.8} \\
K & =\frac{1.49 \times 10^{4}}{\sqrt{0}} \\
D & =\frac{M}{d^{3}}
\end{aligned}
$$

Where $d$ is the missile diameter, $M$ is the missile mass, $\sigma$ is the concrete compressive strength $\left(28.6 \times 10^{6} \mathrm{~Pa}\right)[3], x$ is the target thickness, and $v$ is the missile velocity. Since the cover is not a spherical-nosed missile some approximation must be made for the missile diameter. The most conservative estimate is obtained if we lump all the mass of the cover into a half sphere and use that diameter in the above expression. Taking the missile mass to be $4545 \mathrm{~kg}$ and the material to be steel (density about $7800 \mathrm{~kg} / \mathrm{m} 3$ ) we get an effective missile diameter of

$$
d_{\text {af }}=\left(\frac{12 M}{P_{\text {stoet }} \pi}\right)^{1 / 3}=\left(\frac{12(4545)}{7800 \pi}\right)^{1 / 3}=1.3 \mathrm{~m}
$$

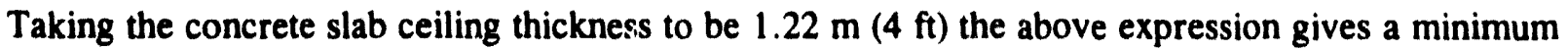
missile penetration velocity of $94 \mathrm{~m} / \mathrm{s}$.

To get a less conservative estimate of the missile penetration velocity, it is assumed that the cover is shaped into a half spherical shell whose thickness, $\Delta$, is $2.54 \mathrm{~cm}(1 \mathrm{in})$. The effective missile diameter under this configuration is

$$
d_{\text {af }}=\sqrt{\frac{2 M}{\rho_{\text {sooof }} \pi \Delta}}=\sqrt{\frac{2(4545)}{7800(\pi)(.0254)}}=3.8 \mathrm{~m}
$$

which yields a minimum missile velocity of $151 \mathrm{~m} / \mathrm{s}$. This is above the impact velocity of $127 \mathrm{~m} / \mathrm{s}$ computed for benzene-air. In reality, the cover would absorb some of the impact kinetic energy in plastic deformation.

The calculated impact velocity for stoichiometric benzene-air is $127 \mathrm{~m} / \mathrm{s}$ compared with the missile penetration velocity computed in the range of $94-151 \mathrm{~m} / \mathrm{s}$. This result indicates that cell cover penetration of the DWPF roof cannot be ruled out based upon the simplified model used here. More detailed calculations involving deformation of the cell cover may demonstrate that penetration is less likely. Such calculations, however, are quite complex. Alternatively, design modifications could be sought to reduce the likelihood of launching of the cell cover. 


\section{References}

[1] WSRC Calc.-Note SRT-PRA-939038.

[2] Gehr, D., Personal Communication (January 1994).

[3] Kennedy, R.P., "A Review of Procedures for the Analysis and Design of Concrete Structures to Resist Missile Impact," Nuclear Eng. Design, Vol. 37, p. 183, 1976.

[4] Nettleton, M.A., Gaseous Detonations, Chapman and Hall, NY, 1987.

[5] Baum, M.R. "Velocity of a Single Small Missile Ejected from a Vessel Containing High Pressure Gas," J. Loss Prev. Process Ind., Vol. 6, No. 4, p. 251, 1993.

[6] Calc. Note SRT-PRA-939076. 
Cell covers

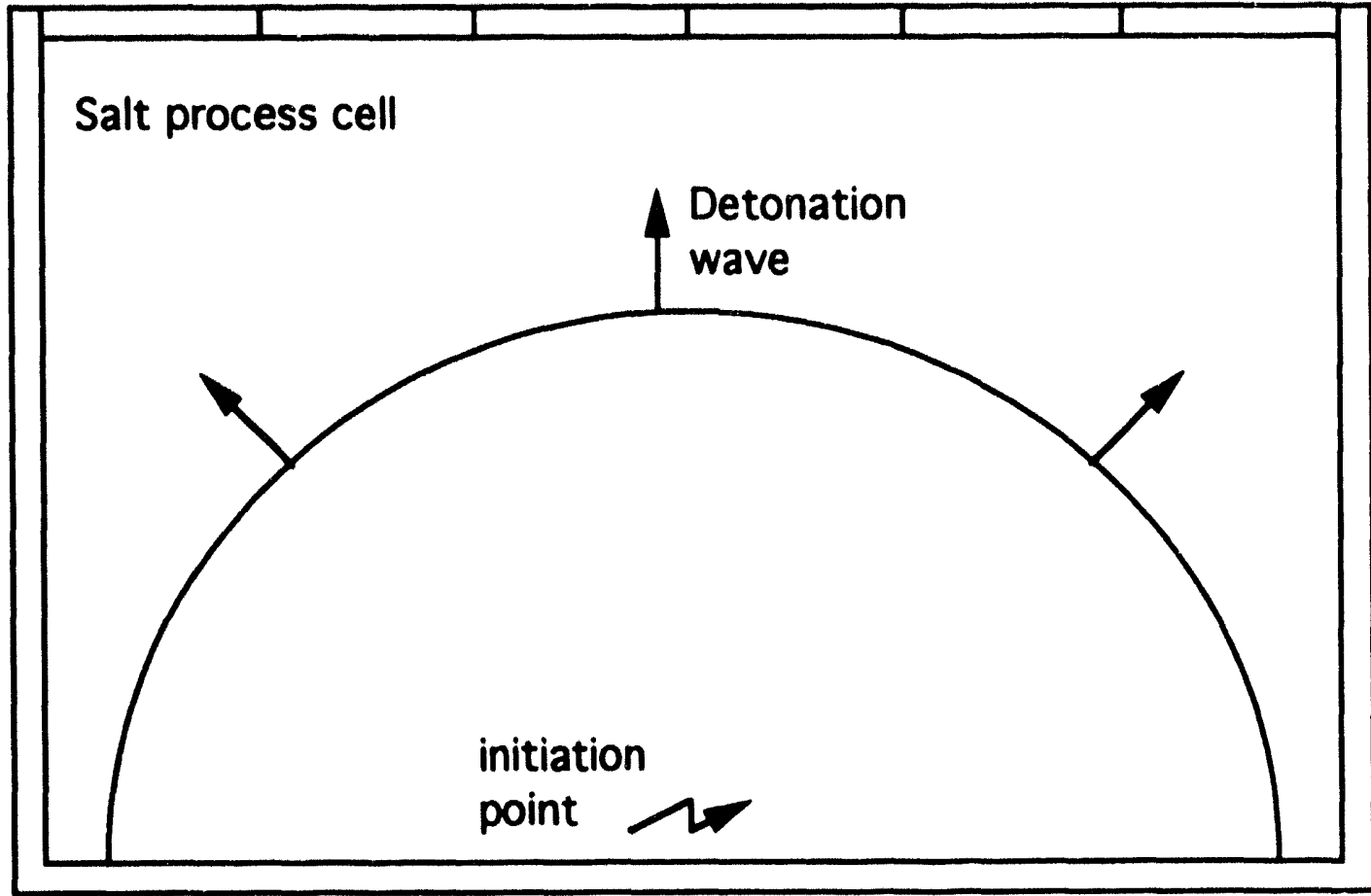

(a)

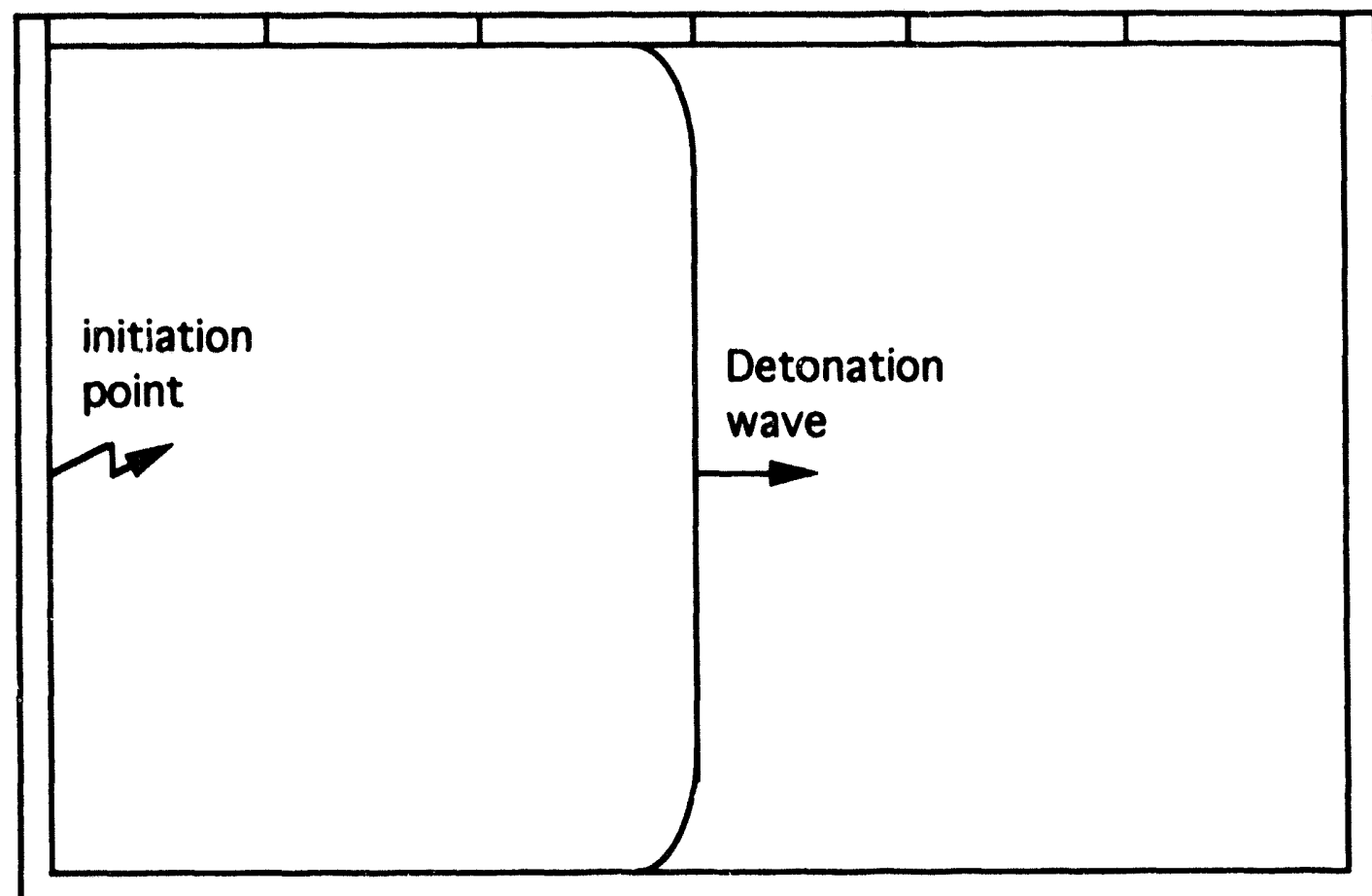

(b)

Figure 1a: Schematic showing propagation of (a) spherical and (b) quasi-planar detonation wave 


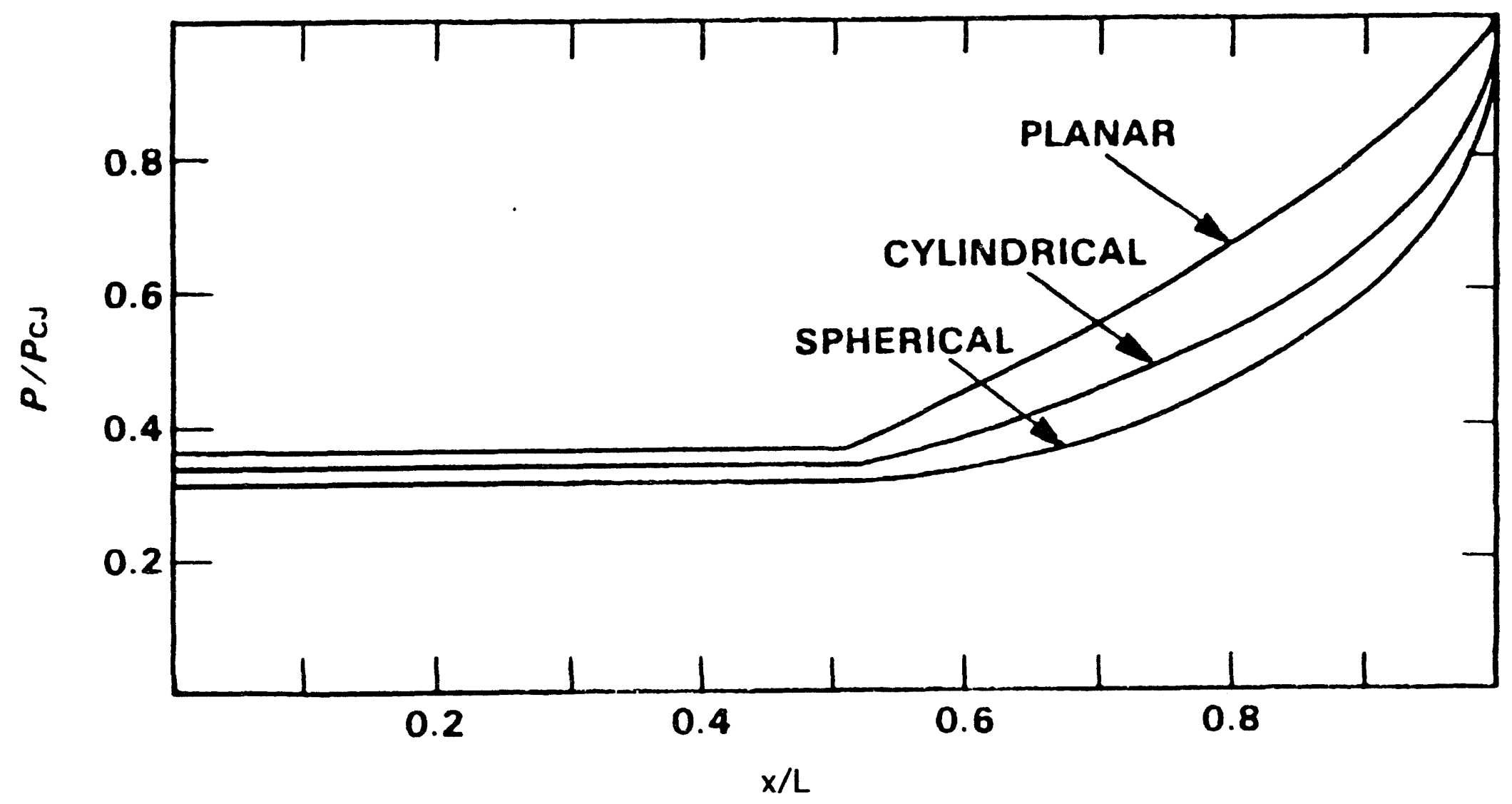

Figure 2: Distribution of pressure behind planar, cylindrical, and spherical $\mathrm{CJ}$ detonations (Nettleton, 1987) 


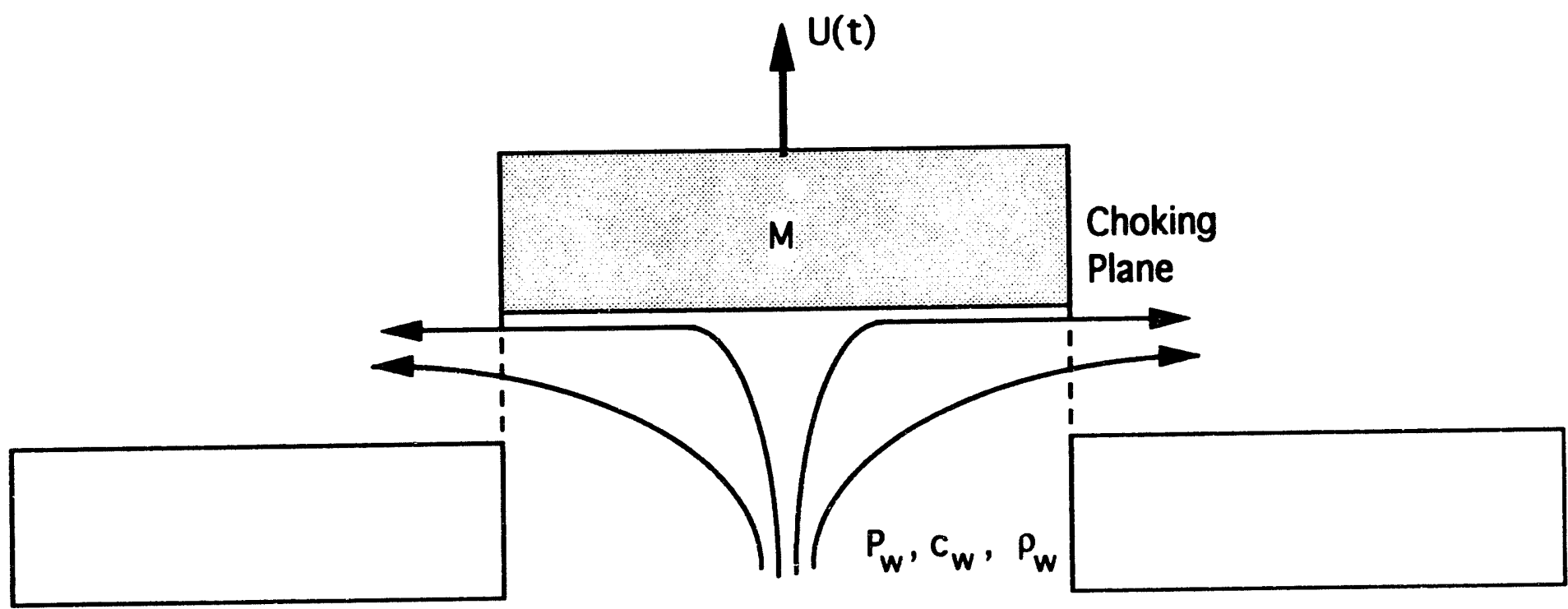

$$
P_{0}(t), c_{o}, \rho_{0}
$$

Figure 3: Schematic showing the location of the choking plane at the gap and the overall flow field from the cell. 
Figure 4: Cover velocity and cell pressure time histories for detonation loading from a stoichiometric benzene-air mixture

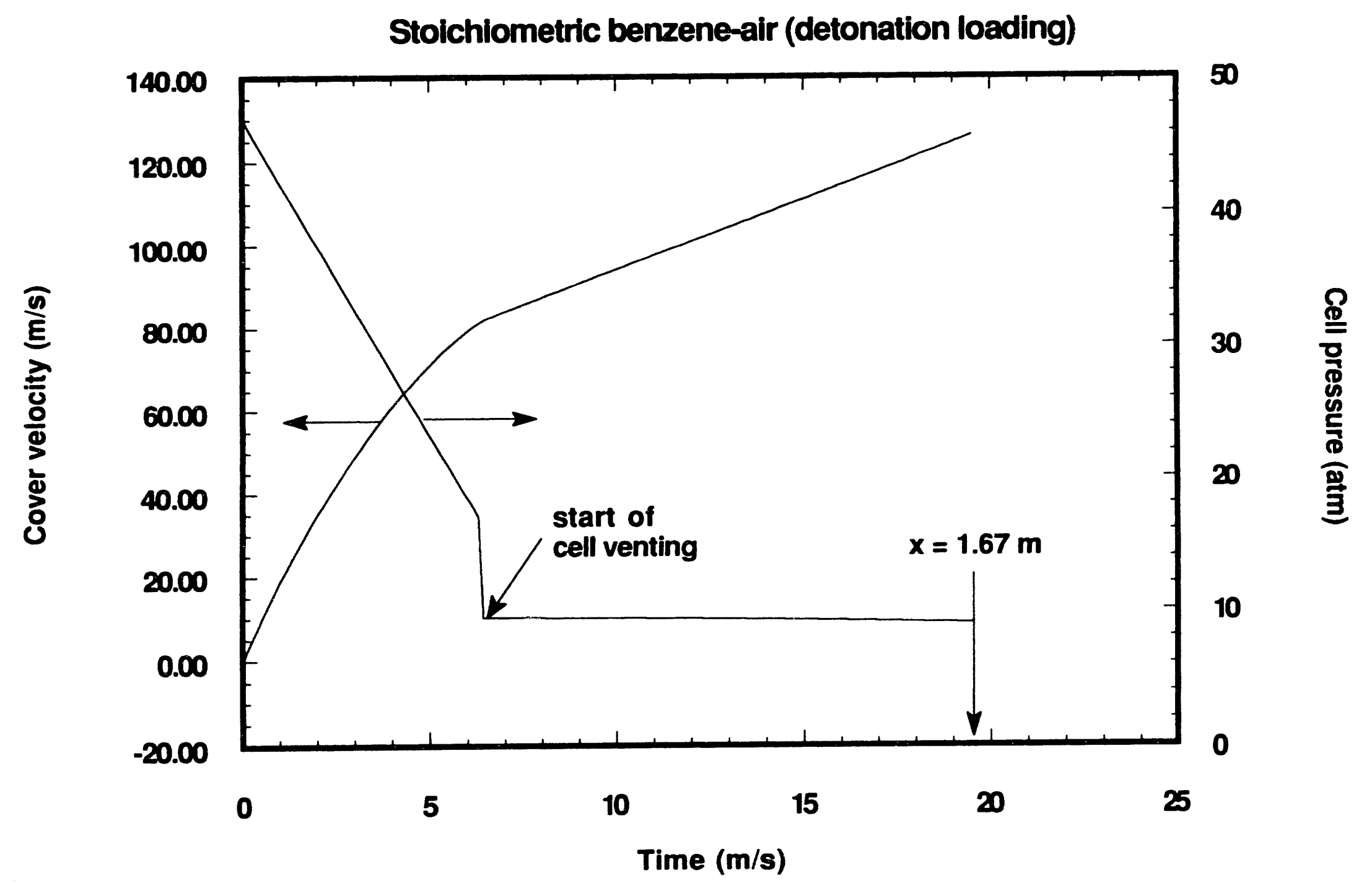


Figure 5: Cover velocity and cell pressure time histories for constant volume combustion loading from a stoichiometric benzene-air mixture

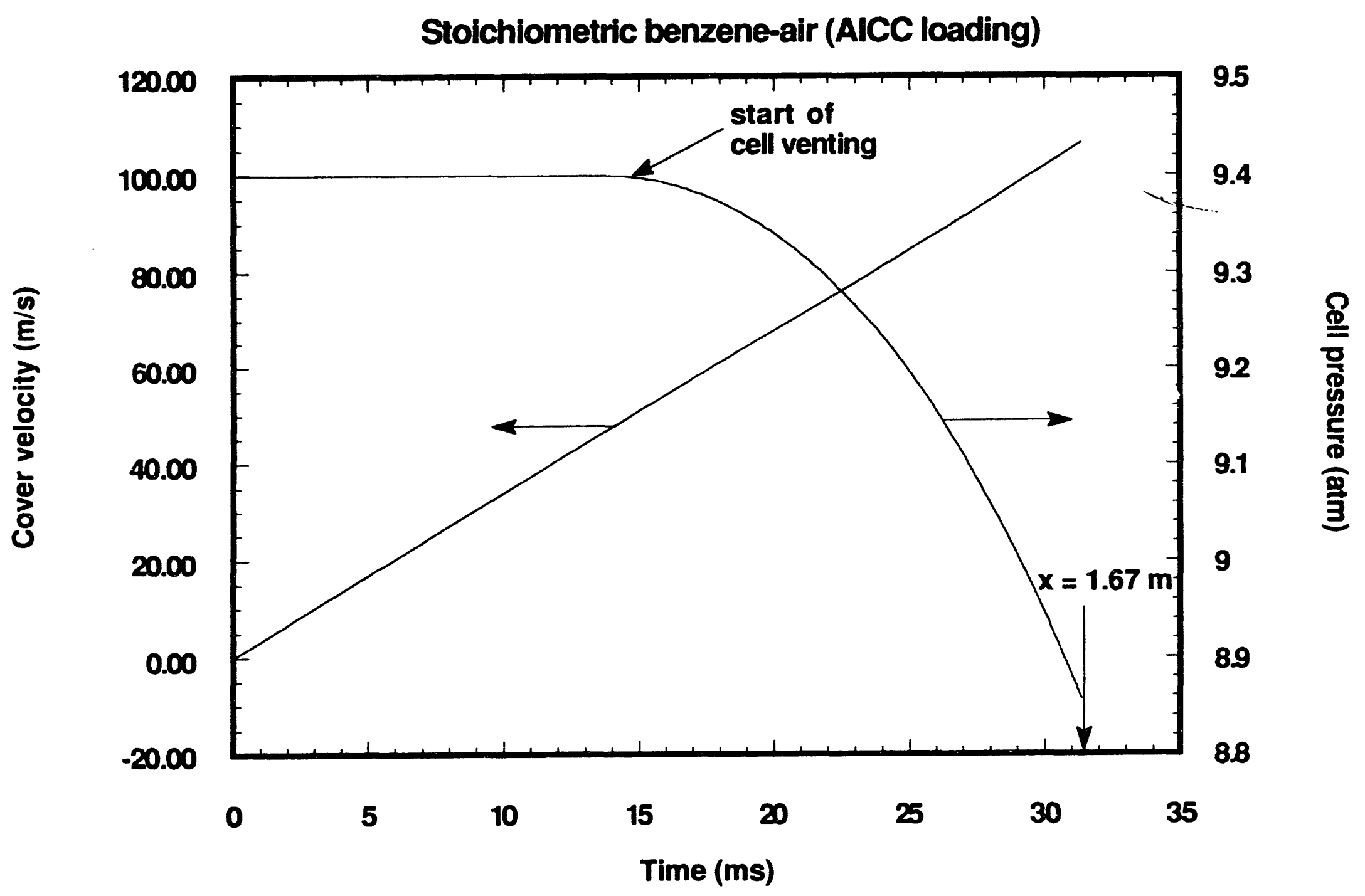




\title{
APPENDIX D
}

\section{QUESTIONS TO WSRC ON ITP WASTE TANK DEFLAGRATION ANALYSIS}

\author{
T. Ginsberg \\ Brookhaven National Laboratory \\ Department of Advanced Technology \\ Safety and Risk Evaluation Division \\ Upton, NY 11973
}

\begin{tabular}{|c|c|c|}
\hline RPPORT & SECTION & QULSTION TO WSRC \\
\hline WSRC-RP-93-542 & 1.0 & $\begin{array}{l}\text { Delineate the possible combustion modes within the ITP waste tanks. } \\
\text { Characterize the potential for detonation in the tanks. What are } \\
\text { potential mechanisms for initiation of a detonation? Are there any pipe } \\
\text { sections connected to the gas space which could be filled with } \\
\text { combustible gas mixture in which a detonation could be initiated and } \\
\text { propagate into the vessel? }\end{array}$ \\
\hline WSRC-RD-93-008 & 2.2 & $\begin{array}{l}\text { Are the burned or the unburned gases assumed tc discharge through the } \\
\text { vents? How does this assumption affect the calculated results? }\end{array}$ \\
\hline WSRC-RD-93-008 & 4.0 & $\begin{array}{l}\text { Has the DPAC code been benchmarked against experiments in which } \\
\text { venting occurred along with combustion? Describe all such } \\
\text { experiments and show the comparisons of experiment and calculation. }\end{array}$ \\
\hline WSRC-RP-93-542 & 2.5 & $\begin{array}{l}\text { How does the available vent area for each of the two tanks compare } \\
\text { with the relief areas computed based upon explosion venting guidelines } \\
\text { of the National Fire Protection Association }{ }^{1,2} \text { (NFPA), for the } \\
\text { maximum allowable pressures of the tanks? Consider this question for } \\
\text { a range of tank inventory and gas mixture composition. }\end{array}$ \\
\hline WSRC-RP-93-542 & 3.0 & $\begin{array}{l}\text { For the vent area available for each of the two tanks, what is the } \\
\text { maximum tank pressure rise predicted for the two tanks based upon the } \\
\text { explosion venting calculation methods recommended by the NFPA? }{ }^{1,2} \\
\text { Consider this questions for a range of tank inventory and gas mixture } \\
\text { composition. }\end{array}$ \\
\hline WSRC-RD-93-008 & 2.2 & $\begin{array}{l}\text { The vents are said to open at } 13 \text { psig. Describe how this specification } \\
\text { was arrived at and how it will be verified during the lifetime of the } \\
\text { plant. }\end{array}$ \\
\hline
\end{tabular}

'National Fire Protection Association, "Explosion Venting," NFPA No. 68, 1978.

${ }^{2}$ See also, Baker, W. E., et al., "Explosion Hazards and Evaluations," Elsevier Scientific Publishing Co., NY, 1983, p. 252-264, Figure 3-22. 


\section{Responses to Office of Nuclear Safety (ONS) Questions to WSRC on ITP Waste Tank Deflagration Analysis \\ (questions from T. Ginsberg, BNL)}

Question 1: Direct initiation of a detonation inside a waste tank, even with a stoichiometric $\mathrm{H}_{2}$-air mixture, is not credible since this requires a very strong ignition source. It is possible that a detonation could be set up in a pipe connected to the waste tank if a sufficiently high hydrogen concentration was accumulated in the line. However, a detonation would not propagate into the tank because the lines are only 3" in diameter: this is below the minimum required for detonation propagation into an unconfined volume even for a stoichiometric mixture of hydrogen with dry air (Sherman 1984, Berman 1986. Guirao et al. 1989). Due to the presence of water vapor and residual inert gas $\left(\mathrm{N}_{2}\right)$, the detonation sensitivity of ITP waste tank mixtures would be expected to be appreciably less. Furthermore, mass transfer back into connecting lines from the tank vapor space would be constricted and hence the hydrogen concentration in the lines would be less than that in the tank, and the iner concentration higher, and hence the critical pipe diameter would actually be much larger than 3 inches.

Question 2: DPAC assumes that the product and reactant gases are vented in proportion to the volume of the waste tank gas space they occupy [discussed in Section 2.2 of Hensel (1993)]. This assumption is justified because the vent area is distributed across the entire tank top and hence product and reactant gases will be vented simultaneously. Preferential venting of product or reactant gas can either lower or raise the calculated pressure depending on the combustion and venting rates.

Question 3 - 5: All benchmark calculations were performed against data from unvented vessel tests: literature data for large vented vessels was not located during this work. The NFPA venting guidelines [e.g. the nomographs provided in NFPA (1988)] are not applicable because: (a) the waste tank vapor space is much larger than in the experiments from which the nomographs were developed. (b) the waste tank vent area distribution differs from that in the experiments from which the nomographs were developed and (c) the nomographs are applicable to a worst-case mixture composition, whereas the expected ITP conditions are more benign. These points are discussed in more detail below.

(a) Vessel Volume: The ITP waste tank vapor space is much larger than employed in the experiments used to construct the NFPA nomographs. The nomographs are based primarily on the work of Bartknecht (1977 and 1981) and Donat (1977). The experiments discussed by Donat (1977) are for vessel volumes of 1, 10, 30 and $60 \mathrm{~m}^{3}$. The data were correlated using the "cubic law" and an enveloping curve developed; the enveloping curve approach is the basis for the nomographs. Of importance to this discussion is the fact that the $60 \mathrm{~m}^{3}$ data fall significantly below the envelope, with the difference increasing as the maximum vessel pressure increases. Bartknecht (1981) notes that the nomographs overpredicts vent area requirements for volumes in excess of $30 \mathrm{~m}^{3}$. For comparison, the vapor space in a half-filled waste tank is $2600 \mathrm{~m}^{3}$. Moore and Bartknecht (1987) explicitly state that the $K$ value used in the cubic law, upon which the nomographs are based, is a volume dependent parameter. 
Barknecht (1981) indicates that at least part of the reason for the decreased vent area requirement at large volume is due to the relatively lower impact of turbulence induced by venting. In a large volume, the localized turbulent region near the vent will not exert as great of influence on the combustion rate as with a small volume; the burn time will therefore be extended, a larger quantity of gas will be vented, and the peak pressure will be reduced. In a small volume, where the tlame is immediately drawn up into the turbulent region near the vent, the combustion rate is greatly increased once the vent is opened.

(b) Vent Location: The data upon which the nomographs are based were taken from experiments in which there was a single vent located away from the ignition source. Once the vent opened, the flame front was pulled towards the vent, increasing its area and the rate of pressure rise. In the case of the ITP waste tanks, the vents are located across the top of the waste tank. The opening of these vents would therefore not act only to pull the flame front towards the vents for vents located in the reactant gas space, but would act to pull the front back for vents located in the product gas space. The net effect would certainly be much less than if all the vents were located ahead of the tlame front.

Several experiments have been reported in the literature which illustrate this point. Eckboff (1987) discusses deflagration experiments conducted with maize starch in a $236 \mathrm{~m}^{3}$ silo vented at the top. Ignition near the bottom or middle of the silo gave peak pressures near those predicted by the German VDI 3673 venting guidelines $(0.1$ to $1 \mathrm{~atm}$.), which are similar to the NFPA guidelines, while ignition near the top of the silo produced essentially no overpressure $(0.01 \mathrm{~atm}$.). Ignition away from the vent resulted in the flame front being pulled towards the vent. which is analogous to the experiments upon which the guidelines were based. Alternatively, ignition near the vent resulted in almost no overpressure.

(c) Mixture Composition: The data upon which the nomographs are based correspond to a worst case gas composition (e.g. slightly hyperstoichiometric mixture of combustible gas with dry air). As mentioned above, the gas mixture present in an ITP tank would also include residual inert gas $\left(\mathrm{N}_{2}\right)$ and water vapor. It is recognized that the data given in the nomographs could be extrapolated to these mixtures on a laminar burning velocity basis.

It is also noted that many of the observations of high pressures in vented vessels reported in the literature are due to acoustic coupling between the vessel and flame front. Strong coupling appears to require a degree of symmetry between the flame front, vent area, and vessel. Such coupling would therefore not be expected in the waste tanks.

On the basis of the discussions given above, it is judged that the NFPA nomographs are not applicable to the waste tanks and that the conservatisms inherent in the DPAC models and input data, as discussed in Section 3.3.1 of Thomas and Hensel (1993), provide sufficient margin to account for any increase in combustion rate due to venting effects.

Question 6: The internal tank pressure at which the vents are assumed to open (13 psig) is based on the riser plug mass and riser area for these tanks [Estochen (1993), discussed in Section 2.5 of Thomas and Hensel (1993)]. This is actually the pressure at which all plugs would be ejected from their risers, some of the plugs would eject at significantly lower pressures. The Waste Tank Farm is in the process of taking steps to ensure these vent areas and will be available throughout the lifetime of the plant. 


\section{References:}

Bartknecht, W. (1977) "Explosion Pressure Relief," Loss Prevention. Vol. 11, (Houston, TX, 21-29 March 1977) Chemical Eng. Prog., Am. Inst. Chem. Eng., New York, NY, pp. 93-105.

Bartknecht, W. (1981) Explosions - Course.Prevention. Protection, 2nd edition, Springer-Verlag, Berlin.

Berman, M. (1986) "A Critical Review of Recent Large-Scale Experiments on HydrogenAir Detonations," Nucl.Sci.Eng, 93: 321-47.

Donat, C. (1977) "Pressure Relief as Used in Explosion Protection," Loss Prevention. Vol. 11, (Houston, TX, 21-29 March 1977) Chemical Eng. Prog., Am. Inst. Chem. Eng., New York, NY, pp. 87-92.

Eckhoff, R.K. (1987) "A Differentiated Approach to Sizing of Dust Explosion Vents: Influence of Ignition Source Location with Particular Reference to Large, Slender Silos." in Industrial Dust Explosions, ASTM STP 958, K.L. Cashdollar and M. Hertzberg, eds., ASTM, Pittsburgh, PA, pp. 265-80.

Estochen, E. (1993) "Vent Area Results," EPD-SE-93-:0022:63, Interoffice Memorandum, Savannah River Site, Aiken, SC, 2/12/93.

Hensel, S.J. (1993) Description and Benchmarking of the Deflagrarion Pressure Analysis Code (DPAC), WSRC-RD-93-008, Savannah River Site, Aiken. SC, April 1993.

Guirao, C.M., R. Knystautas and J.H. Lee (1989) A Summary of Hydrogen-Air Detonation Experiments, NUREG/CR-4961, SAND87-7128, McGill Unv., Montreal, Quebec (under contract to Sandia National Labs), May 1989.

Moore, P.E. and W. Bartknecht (1987) "Extending the Limits of Explosion Suppression Systems," Staub-Reinhalt.Luft, 47(7-8): 209-13.

NFPA (1988) Guide for Venting of Deflagrations (Chapter 6 - "Venting of Deflagrations of Gas Mixtures and Mists in High-Strength Enclosures"), NFPA 68, National Fire Protection Association.

Sherman, M.P. (1984) "Hydrogen Combustion in Nuclear Plant Accidents and Associate Containment Loads," Nucl.Eng.Des., 82: 13-24.

Thomas, J.K. and S.J. Hensel (1993) Pressure Resulting from an ITP Waste Tank Deflagration, WSRC-RP-93-542, Savannah River Site, Aiken, SC, April 1993. 

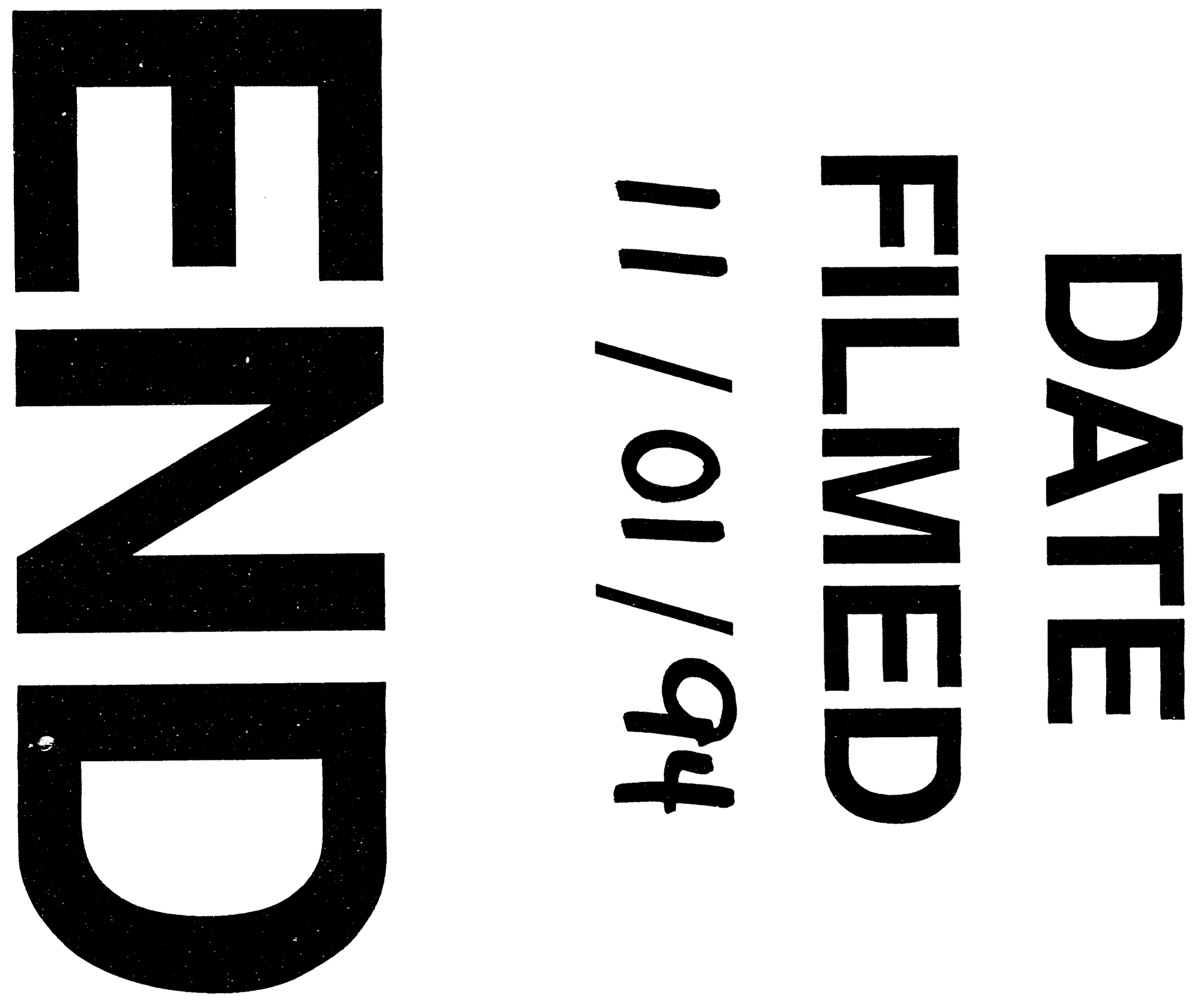
